\title{
Amenities and the geography of innovation: evidence from Chinese cities
}

\author{
Min Zhang ${ }^{1} \cdot$ Mark D. Partridge $^{2,3,4} \cdot$ Huasheng Song $^{5}$
}

Received: 29 October 2018 / Accepted: 15 January 2020 / Published online: 6 February 2020

(c) The Author(s) 2020

\begin{abstract}
Studies in the regional innovation literature have largely focused on the role of economic, structural, demographic, and institutional factors, but very few studies shed light on the role of amenities. This paper investigates this question by examining how amenities shape the geography of innovation in China. The empirical results based on city-level data suggest that both natural and consumer amenities are positively associated with regional innovation. Specifically, amenities related to air quality, sunshine, public transportation, educational resources, and healthcare services matter most. Further, the analysis suggests the influence of amenities on innovation is closely linked to city characteristics such as income, density, and human capital. Therefore, to formulate innovation-driven growth, these results suggest that more attention should be paid to the role of amenities and amenity-related strategies should be tailored to city characteristics.
\end{abstract}

JEL Classification $\mathrm{O} 31 \cdot \mathrm{R} 11 \cdot \mathrm{R} 12$

Huasheng Song

songzju@zju.edu.cn

Min Zhang

minzhangzju@hotmail.com

Mark D. Partridge

partridge.27@osu.edu

1 Dongwu Business School, Soochow University, Suzhou, China

2 Ohio State University, Columbus, USA

3 School of Economics, Jinan University, Guangzhou, China

4 Urban Studies, Gran Sasso Science Institute, L'Aquila, Italy

5 CRPE and School of Economics, Zhejiang University, Hangzhou, China 


\section{Introduction}

Innovation is the creation of new knowledge and the successful implementation of a new product, service, or process, which for most activities entails commercial success (Gordon and McCann 2005). In the modern world, innovation has been typically emphasized as a key path to prosperity. Then, how a region breaks with existing knowledge system and introduces new ideas, products, and services is a question of policy significance. So far, many researchers have examined the innovation process by appraising the relative motors of regional innovation output. Most of these studies have focused on economic factors such as R\&D and human capital (e.g., Feldman and Florida 1994; Sun 2003; Stephens et al. 2013), the role of agglomeration economics (Lee and Rodríguez-Pose 2014), demographic and institutional context of local economies (Sleuwaegen and Boiardi 2014; Fitjar and Rodríguez-Pose 2015; Crescenzi and Rodríguez Pose 2017), or factors influencing spatial linkages (Song and Zhang 2017).

Yet, one potentially key factor behind the growth of Chinese regional innovation has been largely overlooked: the role of amenities in enabling the development of innovative activities. Being a key factor behind quality of life, amenities are defined as site- or region-specific goods and services that affect regional attractiveness for its workforce (Mulligan and Carruthers 2011). These amenities include climatic features, beauty and accessibility of the natural environment, landscape, public services, safety, or the vibrancy of a region's cultural milieu (Roback 1982; Gyourko and Tracy 1991; Dalenberg and Partridge 1997; Deller et al. 2001; Rappaport 2007). Conversely, disamenities are factors that make places unattractive such as extreme weather, air pollutants, and crime. Since amenities have been found to be important factors in driving household and firm location in developed countries (e.g., Rappaport 2007; Partridge 2010), it seems reasonable to assume that amenities may play a significant role in shaping the geography of innovation, especially if they are attractive to skill workers.

While China is still considered a developing country, over the past 30 years, its economy has experienced the same type of changes that led to amenity-driven migration and growth in more developed countries. For example, Chinese per-capita GDP has usually grown more than 8 percent per year since 1993 (World Bank). Additionally, internal migration barriers have decreased due to reforms in the "Hukou" system and rapid advances in transportation and information technology. Because Chinese households are now more educated and wealthier, they are seeking

\footnotetext{
1 The 'Hukou' household registration system in China was implemented in the 1950 s to register people by their hometown origin and by urban versus rural status for the purpose of regulating migration. The system limited the ability of migrants without local Hukou to purchase houses or access public services such as public primary and middle schools and healthcare. However, the liberalization of both urban housing and labor markets over the past decades significantly lowered labor-mobility barriers and afforded the Chinese enhanced freedom in choosing urban locations to live and work (Zheng et al. 2010). Nowadays, to attract and retain high-skilled workers, local governments are assigning local Hukou quotas to migrants with undergraduate and graduate degrees, which means that barriers from the Hukou system for high-skilled migrants are smaller than that of less-skilled ones.
} 
out locations that offer a higher non-market quality of life (Zheng et al. 2009; Zheng and Kahn 2013a).

Figure 1 maps the spatial distribution of innovation intensity in China in 2007 and 2014, respectively, in which innovation intensity is measured by per-capita patent applications. They show that patenting activities are spatially concentrated in coastal China, especially in the most economically developed areas in the Yangtze River delta and Pearl River delta. Meanwhile, clusters of innovation are expanding over time. For example, from 2007 to 2014, joining coastal cities, some central and eastern cities such as Chengdu, Jinan, and Hefei were also among the most innovative poles, pointing to a decentralized process. Correlation test results also show innovation and air pollution are inversely related. (The correlation coefficient between concentration of PM2.5 and patenting intensity is -0.31 and significant at the 5\% level during the period 2007-2010 when we have data.) As air pollution is a disamenity, it then suggests a positive correlation between innovation and desirable amenities. However, more evidence is needed to assess the positive and significant relationship.

Given that high-skilled workers (who are most likely to be high-income) are more strongly attracted to amenities (because amenities are typically normal goods) than less skilled workers, there should also be a positive relation between the output of these high-skilled workers (including innovation) and a given location's level of amenities. Thus, amenities likely influence where innovation takes place by affecting the geographical distribution of highly educated workers.

Therefore, this paper aims to explore the question of whether amenities play a role in determining the geography of innovation in China. In answering this question, we offer several contributions to the literature. First, this study concentrates on the role of amenities in affecting Chinese regional innovation, which has attracted surprisingly little scholarly attention given that amenities are thought to be increasingly important as China becomes wealthier. Second, the paper is the first to discuss the heterogeneous impact of amenities at the city level, which is an extension of studies exploring the heterogeneous effects of amenities at the individual level. Third, both natural amenities and consumer amenities are considered. Due to concerns regarding endogeneity from consumer amenities, previous studies have rarely included consumer amenities. Yet, by utilizing a matching instrument approach to address the endogeneity problems, this paper considers both the impact of natural amenities and consumer amenities. Finally, because we use city-level data, our conclusions are more applicable than the past literature that primarily used provinciallevel data (e.g., Sun 2000, 2003; Li 2009; Crescenzi et al. 2012; Fan et al. 2012; Fan 2014).

In what follows, Sect. 2 overviews the literature on the determinants of regional innovation. Section 3 presents mechanism analysis on the impact of amenities on regional innovation by justifying the relationship between amenities and regional innovation. Section 4 introduces the empirical model, variables, and estimation strategies. The key results are in Sect. 5, and a discussion of the mechanisms is in Sect. 6. Section 7 provides further heterogeneity analysis to investigate whether the impact of amenities is place-based. Finally, Sect. 8 concludes and discusses policy implications. 

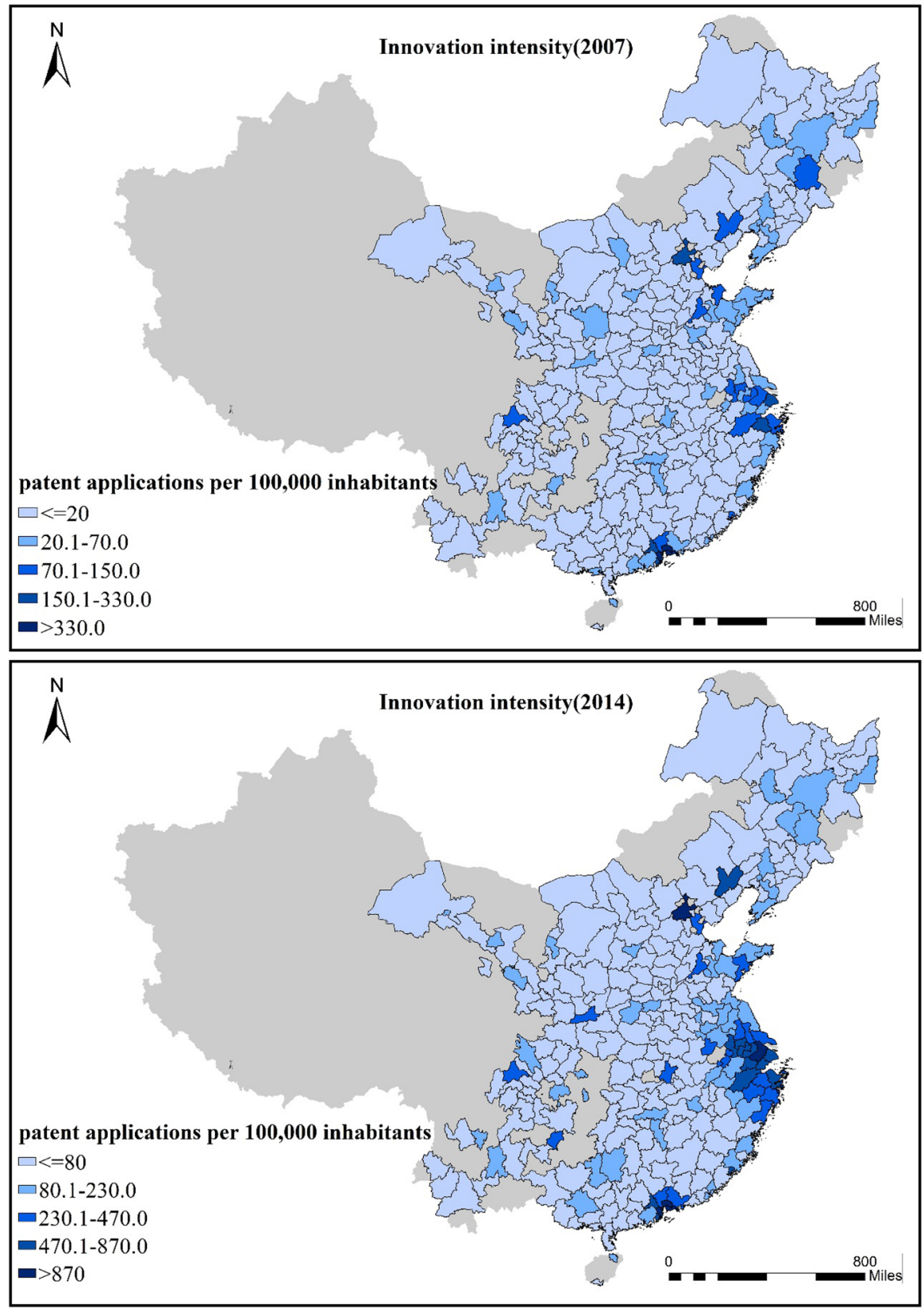

Fig. 1 The geographical distribution of innovation intensity $(2007,2014)$ 


\section{Drivers of regional innovation: literature review}

There are many factors thought to drive regional innovation. To begin with, according to Griliches (1979), the innovative-related inputs such as research and development (R\&D) and human capital are required for innovative processes (e.g., Co 2002; Gordon and Mccann 2005; Rodríguez-Pose and Crescenzi 2006; Chen and Kenney 2007; Faggian and McCann 2009; Smit et al. 2015; Fitjar and Rodríguez-Pose 2015; Kafouros et al. 2015; Crescenzi and Jaax 2017). Yet, merely R\&D efforts and human capital are by no means sufficient to explain regional-level innovative performance. An extensive literature has shed light on the role of other socioeconomic, demographic, and institutional factors.

There is a consensus that innovative processes are more productive in economically aggregated regions. The New Economic Geography emphasizes agglomeration economies as the main motor of economic growth and innovation production (Fujita and Thisse 2003; Gordon and Mccann 2005; Kuckiki and Tsuji 2010; Crescenzi and Jaax 2017). Concentration of people and economic activities is supposedly helpful in terms of accelerating the transmission of information. Also, face-to-face contacts constitute economically efficient means for the transmission of generally considered "sticky" but valuable knowledge (Morgan 2004). The effectiveness of agglomeration economies in creating a supportive context for generating new knowledge has also been documented by ample empirical evidence (e.g., Gordon and McCann 2005; Fitjar and Rodríguez-Pose 2015; Rodríguez-Pose and Crescenzi 2008; Kafouros et al. 2015; Crescenzi and Jaax 2017).

The innovative processes have also been linked to the industrial structure of local economics and institutions. Fitjar and Rodríguez-Pose (2015), for instance, suggest that the structural factors constitute the conditioner or processes of regional innovation. As highlighted by several authors, institutional conditions and demographical and social factors have made the relationship between innovative efforts and the generation of new knowledge far from a linear process (Agrawal et al. 2008; Rodríguez-Pose and Crescenzi 2008; Kafouros et al. 2015; Smit et al. 2015; Rong et al. 2017; Wu et al. 2017).

The openness of a region as reflected by FDI and trade is also assumed to affect local innovation performance. Crescenzi and Jaax (2017), for example, conclude that trade is the "global knowledge pipeline". Spatial spillovers through geographical proximity are another route that promotes innovation (e.g., Agrawal et al. 2008; RodríguezPose and Crescenzi 2008; Smit et al. 2015; Rong et al. 2017; Wu et al. 2017).

In addition to the above factors, amenities could be another key determinant of regional innovation. However, very few studies have attempted to identify and assess the impact of amenities on regional innovation. To date, a handful of recent papers have provided hints to this question. For example, utilizing 2013-2015 US census block data, Zandiatashbar and Hamidi (2018) find that amenities (related to transit service quality and walkability) along with diversity and tolerance are significant influential factors of local knowledge economy in the USA. Based on data for an older downtown area in a Chinese province, He et al.(2018a, b) find landscape amenities, leisure, and creativity networking opportunities are 
important factors in explaining the spatial concentration of photography studios in Nanjing, China-though we caution that generalization from case studies can be limited.

\section{Amenities and innovation: mechanism analysis}

Existing studies of developed countries offers several hints why amenities are important for innovation development, which we classify into two strands. First, amenities affect innovation by increasing the supply of skilled workers; second, amenities may further increase innovation because amenities benefit the health and attitudes of the workforce, which increases their productivity. Following the two strands of literature, we justify the relationship between amenities and innovation output in what follows.

\subsection{Amenities attract talent with high levels of human capital}

Amenities affect innovation activities by helping to retain and attract skilled workers. According to Florida (2002a), amenities play a crucial role in innovation and economic development in this manner. Florida defines talent as highly educated people, professional and technical workers, scientists, and engineers, all of whom help generate innovations. Holding other local conditions constant, amenities attract talent, which in turn attracts high-technology industries that produce more regional innovation. Yet, such a causal relationship is based on two preconditions: First, high-skilled workers are geographically mobile. Second, there is a limited supply of high-skilled workers, which implies that the labor market for these workers is affected by their location choices. In such a scenario, high-technology firms will be attracted to locations with a greater supply of high-skilled workers.

Many empirical studies support such an amenity growth strategy. For example, Glaeser et al. (2001), Adamson et al. (2004) find a positive association between amenities and city growth. Li et al. (2016) suggest that high-growth firms exist in counties with higher educational attainment and more natural amenities.

More specifically, according to some survey studies, environmental amenities, good schools, and public services are important site-specific factors in location choice for both households and firms. For example, Stafford et al. (1984) found that quality of life is ranked seventh out of ten factors for all plants in choice of region but third out of ten for high-tech facilities. Focusing only on R\&D facilities, Lund (1986) found that quality of life is ranked first out of six factors. Thus, innovative firms and research institutes that are actively engaged in innovation are typically attracted to amenable places.

\subsection{Amenities affect labor productivities}

If high-skilled workers have low mobility across regions and their bargaining power in the labor market is limited, regions are unlikely to be affected by the amenity factors as described above. Even in this case, there is another possible channel through which amenities affect regional innovation, i.e., by affecting worker productivity. 
Individual workers' mood and creativity may be linked to their location's amenities and culture. Places with open space, nice climate, surrounded by lakes, greenspace, and consumer services will likely have happier workforces and improved productivity-especially if creativity is required (Wu and Dong 2014; He et al. 2018a, b). According to Carlino and Saiz (2019), the package of environmental, esthetic, and recreational amenities is complementary to the enjoyment of leisure that in turn improves psychological welfare-thereby making people more productive. Conversely, the opposite applies when there are disamenities. For example, according to the psychology literature, exposure to ambient air pollution reduces cognitive ability, as well as increases anxiety and boredom (Lavy et al. 2014; Pun et al. 2017). Additionally, other studies reveal that air pollution harms human health, shortens life expectancy, reduces the return of human capital (e.g., Chay and Greenstone 2003; Neidell 2004; Currie and Neidell 2005; Rundell 2012; Chen et al. 2013; Sun et al. 2019). Therefore, all else equal, more amenable environments enhance worker productivity, especially for knowledge workers.

The economics literature further illustrates how labor productivity is affected by air quality. For example, Zivin and Neidell (2012) suggest that ozone concentration in the air affects those who are outdoors. By measuring how labor productivity changes, empirical studies from the USA, India, and China all suggest that the efficiency of piece-rate workers declines during days with higher concentrations of PM2.5 and SO2 air pollutants (Adhvaryu et al. 2014; Chang et al. 2016; He et al. 2018a, b). The adverse effect of air pollutants on athletic performance provides other examples. For example, German baseball athletes perform worse as CO, PM10, and PM2.5 air concentrations increase (Lichter et al. 2017; Archsmith et al. 2018). Using a sample of over 300,000 marathon runners in 55 events in 37 Chinese cities, Guo and Fu (2019) find that a one standard deviation increase in air pollution slows a runner's time by $2.6 \mathrm{~min}$. Therefore, we infer that air quality likely affects $R \& D$ activities and innovation. Likewise, access to good schools, healthcare, restaurants, as well as cultural and historical amenities such as museums could have similar effects on innovation (though this is also an empirical question).

This compelling evidence of the influence of various amenities on local productivity and their attractiveness to high-skilled workers calls for a comprehensive framework to assess the impact of amenities on Chinese innovation. Previous research emphasized the importance of R\&D, human capital, agglomeration, industrial factors, and spatial spillovers in explaining regional innovation. This paper extends this literature by showing that increased provision of consumer amenities and a more amenable natural environment can also support innovation growth.

\section{Empirical model and data}

\subsection{Model specification}

Several theories have been put forward to explain the geography of innovation. Innovation is the return of investment in human capital and research and development (R\&D) spending (Griliches 1979, 1986; Jaffe 1986). The New Economic Geography 
(NEG) approach highlights the role of agglomeration economies to explain differing innovation performance (e.g., Acs et al. 2002; Carlino et al. 2007). Furthermore, the literature on regional innovation systems emphasizes economic structural factors such as industry composition and the level of economic development in determining innovation (Rodríguez-Pose and Crescenzi 2008; Crescenzi et al. 2012; Crescenzi and Rodríguez Pose 2013). However, Rodríguez-Pose and Wilkie (2016) note that, as significant geographical heterogeneity can exist between any two countries, it is hard to find a general spatial model of innovation applying to any country. Some examples of papers that explore regional-level innovation include Crescenzi et al. (2007, 2012), Rodríguez-Pose and Crescenzi (2008), Crescenzi and Rodríguez Pose (2013), Lee and Rodríguez-Pose (2014), Rodríguez-Pose and Villarreal Peralta (2015), Betz et al. (2016). Following this literature, we specify the model as follows ${ }^{2}$ :

$$
\text { inno }_{i, t}=\alpha+\alpha_{1} \text { amenity_natural }{ }_{i, t-1}+\beta_{1} \text { amenity_consumer }_{i, t-1}+\alpha_{2} X_{i, t-1}+\mu_{i}+v_{t}+\varepsilon_{i t}
$$

where inno $_{i, t}$ represents innovation outcome at time $\mathrm{t}$ in city $\mathrm{i}$; amenity_natural ${ }_{i, t-1}$ and amenity_consumer ${ }_{i, t-1}$ are the natural amenity and consumer amenity variables at time t- 1 in city i, respectively. $X_{i, t-1}$ is a set of control variables. $\mu_{i}$ and $v_{t}$ stand for city and year fixed effects, and $\varepsilon_{i t}$ represents the residual. The coefficients of interest are $\alpha_{1}$ and $\beta_{1}$ in model (1). To mitigate potential endogeneity problems caused by reverse causality, we lag all the time-varying explanatory variables by one period. Endogeneity concerns will be further discussed below.

\subsection{Variables}

\subsubsection{Dependent variable}

The dependent variable proxies for innovation intensity are per-capita patent applications, ${ }^{3}$ which have been accepted as the most appropriate measure of innovation performance (e.g., Mansfield 1986; Griliches 1990; Hagedoorn and Cloodt 2003; Mate-Sanchez-Val and Harris 2014).

\subsubsection{Amenity variables}

The definition of amenities can vary across studies. Natural amenities were the main focus-e.g., Ullman (1954) defined amenities to include mountains, warm climate, lakes, and oceans. For example, U.S. Department of Agriculture ranks US counties for natural amenities defined as temperature in January and July, hours of sunshine,

\footnotetext{
${ }^{2}$ Note that the most significant difference between our study and the past literature is our focus on the role of "amenities," whereas past work stresses the role of R\&D and spillovers to explain innovation.

${ }^{3}$ Another reason for using this measure is that other indicators for innovation used in the USA or European context are unavailable (especially at the prefecture level) for China such as the number of inventors (Crescenzi et al. 2016) or information on firm-level process and product innovations (Fitjar and Rodríguez-Pose 2011).
} 
humidity, topography, and proximity to large bodies of water, in which the index is widely used in the literature (e.g., Betz and Partridge 2013; Betz et al. 2016).

Consumer amenities, also known as manmade amenities or urban amenities, have long interested researchers and policymakers (Rosen 1974; Roback 1982; Gyourko and Tracy 1991; Dalenberg and Partridge 1997; Glaeser and Shapiro 2002; Bayer et al. 2009). For example, Brueckner et al. (1999) refer to consumer amenities to historical sites (e.g., monuments, buildings, parks), and services such as restaurants, theaters, swimming pools, and tennis courts. Glaeser et al. (2001) define consumer amenities to include a rich variety of factors such as restaurants, theaters, an attractive mix of social partners, aesthetics, physical setting, good public services, low crime, and short commutes.

Perception toward what constitutes an amenity varies case by case (He et al. $2018 \mathrm{a}, \mathrm{b})$, making each "amenity" a contextualized term that requires a localized and situational understanding. Since the analysis is rooted in Chinese context, the selection of amenity variables is based on preferences of Chinese households during the period. By consulting the literature and taking the institutional environment(as well as the media) into account, this paper selects climate and air quality as natural amenities and includes public transportation, healthcare resources, educational resources, and tourism to indicate consumer amenities. ${ }^{4}$ Specifically, we choose the following natural amenity measures: average temperature, precipitation, humidity, sunshine hours, air quality, and green areas. Because climate data are only available for the provincial capital, we assign those values for non-capital cities in the province. ${ }^{5}$ We also follow Zheng et al. (2010) and construct a composite index of temperature comfort as defined by the following equation:

$$
\text { temindex }_{\mathrm{i}}=\frac{1}{\sqrt{\left(\text { mintem }_{i}-\text { average }_{i}\right)^{2}+\left(\text { maxtem }_{i}-\text { average }_{i}\right)^{2}}}
$$

where, for prefecture $i$, 'average $\mathrm{e}_{\mathrm{i}}$ ' is the average annual temperature, while 'mintem ${ }_{\mathrm{i}}$ ' and ' maxtem $_{\mathrm{i}}$ ' refers to the average temperatures in January and July, respectively. In general, this index measures whether the city faces extreme temperatures over the year-a greater 'temindex ${ }_{\mathrm{i}}$ ' represents smaller temperature extremes.

Taking the institutional context of China into account, a list of factors is chosen to proxy for consumer amenities including public educational resources, healthcare services, transportation, infrastructure, and high-quality tourist attractions. For example, due to the restriction of "Hukou" system, public educational resources for primary and secondary schools and healthcare resources are primarily available for households with local "Hukou" status especially in large cities such as Beijing and

\footnotetext{
${ }^{4}$ Other time-invariant city characteristics, such as proximity to the ocean, scenic views, historic districts, architectural beauty, and cultural, and recreational opportunities are incorporated in the city fixed effects. Although changing the estimation method to (say) a random-effects model may help identify the impact of all time-invariant factors, the omission of city fixed effects will bias the random-effects estimates.

5 This assumption may introduce measurement error, but it will only bias the climate variable coefficients down to zero, resulting in an underestimation of the effects of the climate.
} 
Shanghai (Chan 2009; Bosker et al. 2012). Consequently, the availability of public educational resources becomes one of the most important factors that Chinese households consider in their residential location choice (Liu and Shen 2014; Su et al. 2019).

The key features of what we define as amenities are those that are most easily assessed by local residents. In China, a few features stand out as key amenities that affects skilled workers' location choice including primary and secondary schools, healthcare services, etc. Since the 1980s, rural residents have moved to urban areas for better careers and higher quality of life, while the supply of public services in cities was strained to meet the increased demands of residents and new migrants. Thus, local governments use the Hukou registration system as a way to erect barriers between those who hold local Hukou and non-holders by allowing only the local Hukou holders to fully access public services. ${ }^{6}$ Though Hukou status is no longer a constraint for finding a job in cities, it remains an important tool for rationing access to local public services such as schools, healthcare and social security benefits (Zheng and Kahn 2013b). The scarcity of public service resources and the existence of Hukou system exactly reflect that the amenities related to Hukou system are valuable for workers, especially amenities with regard to good schools and quality healthcare services. By contrast, environmental amenities such as green areas, air quality, and consumer amenities such as public safety, universities, sports, tourismand-entertainment facilities and services are not exclusive to non-Hukou holders.

Specifically, we adopt per-capita public primary and middle schools to proxy for amenities related to educational resources (ppschool, pmschool). We also count the number of 4A and 5A Grade Tourism and Vacation Zones for each city to reflect the attractiveness of natural, cultural and historical sites. In addition, we will include per-capita school and healthcare resources-i.e., the number of primary and middle schools (mschool, pschool) and healthcare institutions (bed).

To reveal the overall amenities for each prefecture city, we construct two composite indexes for natural amenities and consumer amenities by means of principal component analysis (PCA). Using PCA allow us to expurgate the redundancies while maintaining the key features of the amenity indicators (e.g., Fagerberg 1988; Crescenzi et al. 2007, 2012; Crescenzi and Rodríguez Pose 2013; Rodríguez-Pose and Villarreal Peralta 2015; Rodríguez-Pose and Zhang 2019). The elements used to construct our natural amenity index are the natural amenity variables described above. Similarly, the consumer amenity index is created by combining the corresponding consumer amenity indicators. The final indexes we construct follow expectations. For example, comfortable temperatures and the climate have positive weights, while a negative weight is assigned to air pollution. We therefore adopt the constructed index as a proxy for the overall amenities in each city. The test results for the first principal component analysis are reported in Table 5 in "Appendix."

\footnotetext{
${ }^{6}$ As indicated before, to attract and retain high-skilled migrants, local government are assigning less restrictive local Hukou quotas to migrants based on a score system, with undergraduate and graduate degree holders more likely to be granted local Hukou in the migrant city and even receive substantial subsidies, which means the barriers from the Hukou system for high-skilled migrants are smaller than that of the less-skilled ones. In the Chinese context, the attractiveness of a city for its migrants is related to its attractiveness of public goods and services.
} 


\subsubsection{Control variables}

The control variables include measures for R\&D expenditures, human capital, agglomeration economies, population density, manufacturing activity, and economic wealth. Including these factors help control for structural and economic development differences across geographical location. The variable definitions and data sources are given in Table 1. Table 6 in "Appendix" provides descriptive statistics. The data are drawn for the 281 prefecture cities $^{7}$ and span from 2007 through 2014 for a total of 2248 observations.

\subsection{Estimation strategy}

We first estimate model (1) by ordinary least square (OLS) assuming that all of the amenity variables are exogenous, given that natural aspects are predetermined for each city. ${ }^{8}$ Later, we use an instrumental variable (IV) estimation strategy to re-estimate model (1) to account for any potential endogeneity of the consumer amenity variables. For example, consumer amenities that cater to the affluent may promote innovation or innovation growth and can stimulate the supply of consumer amenities for high-income individuals (Kahn and Zheng 2016, p. 84). To mitigate these endogeneity concerns, we assume innovation is an outcome of returns of past investment in human capital and other innovation inputs. Thus, all the explanatory variables are lagged one period. ${ }^{9}$ Because omitted variables may also bias the results, we account for city fixed effects and year fixed effects to control for time-invariant city effects and national common trends. (Graves and Mueser 1993; Brueckner et al. 1999)

In addition to the fixed-effects specification, we also apply instrumental variables (IVs) to address possible endogeneity caused by omitted variables. Specifically, we follow an approach similar to Autor et al. (2013) and more specifically Partridge et al. (2017) by using a matching process to obtain suitable instruments for consumer amenities. The basic idea of this approach is to construct two "counterfactuals"10 for each city. Specifically, the first step is to find the two best city matches

\footnotetext{
7 Due to missing data, boundary changes, and extreme values, we omit 12 out of 293 Chinese cities from the sample. The missing data are primarily from far western China.

${ }^{8}$ For example, innovation is unlikely to influence air pollution because most Chinese manufacturing firms (including the greatest polluters) are located in large coastal cities that are also home to the greatest innovators. According to China City Statistical Yearbook data, in 2007, the top twenty cities in terms of manufactory employment are Shanghai, Beijing, Shenzhen, Suzhou, Guangzhou, Quanzhou, Tianjin, Qingdao, Hangzhou, Chongqing, Huizhou, Wenzhou, Xiamen, Jiaxing, Harbin, Ningbo, Xi'an, Yantai, Wuhan, and Dalian. And all of these cities are either first-tier or top second-tier cities. This pattern implies that local innovation is not causal for the deterioration of air quality.

${ }^{9}$ Lagging all the explanatory variables by one period may not fully solve any endogeneity problems. We also tried cross-sectional models with the explanatory variables measured in the initial year-i.e., the dependent variable is innovation intensity in 2014, while the explanatory variables are amenity variables and control variables measured in 2007. Yet, the corresponding regression results are quite similar. Considering that the cross-sectional sample size is greatly reduced, we only report the panel results as the base model.

${ }^{10}$ A key advantage of including two instruments is that we can conduct a Sargan test for overidentification.
} 


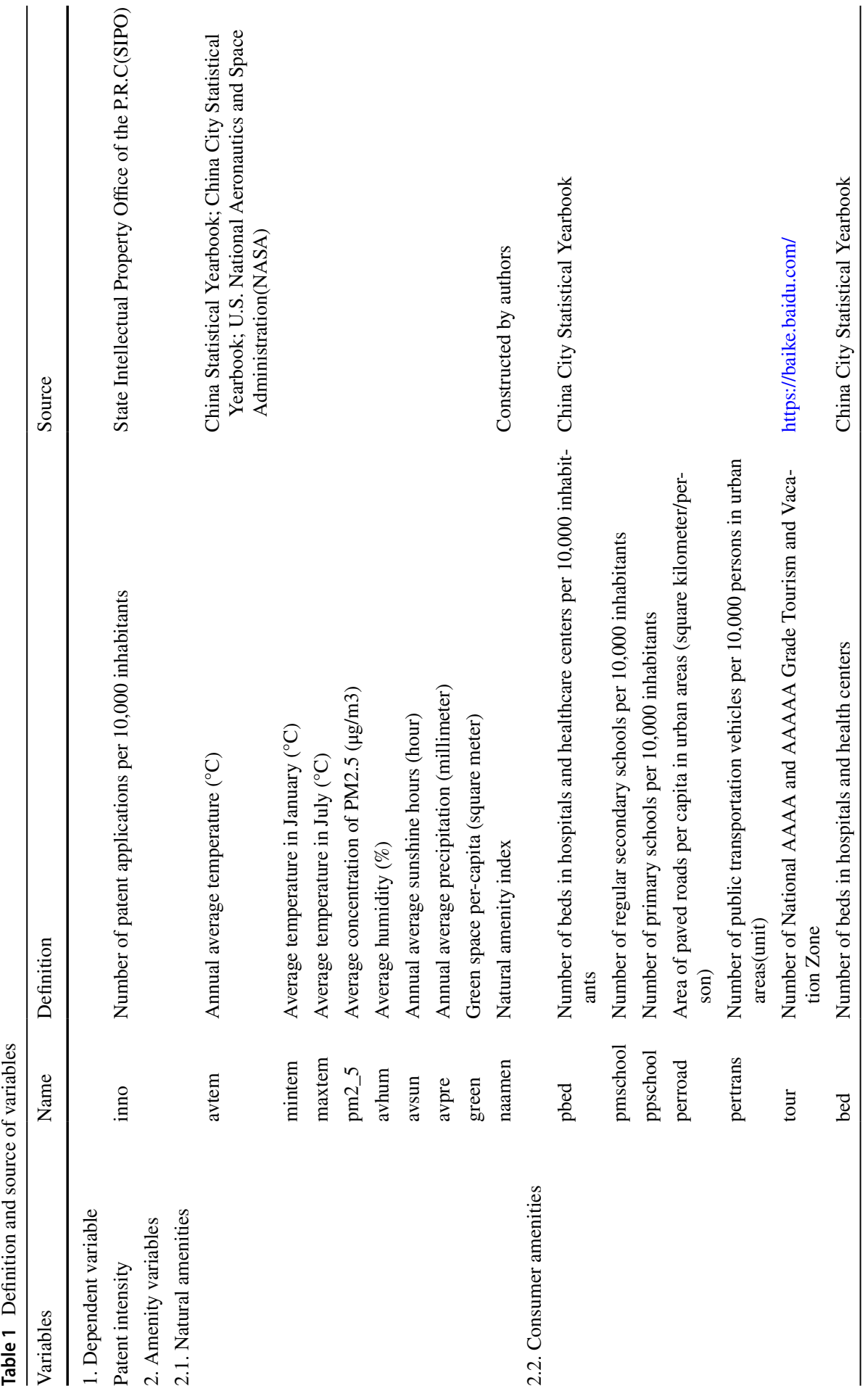




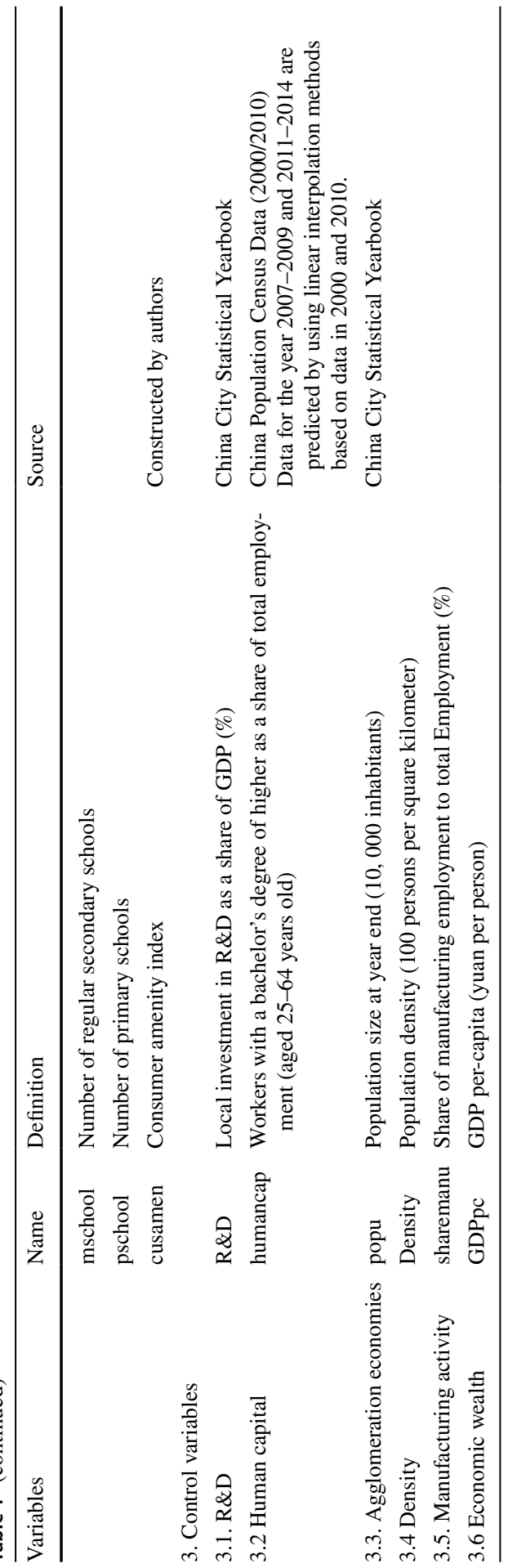


for each city based on their initial-period 2007 per-capita GDP (GDPpc), average years of schooling (avedu), agglomeration (рори), and density (popudensi) using the Mahalanobis distance approach for matching. ${ }^{11}$ To reduce the bias from spillover shocks that would invalidate the counterfactual, we set the minimum Euclidean distance between the matches of at least $200 \mathrm{~km}$. Coastal city matches are restricted to other coastal cities and matched cities for inland cities are only chosen from other inland cities. In the second step, we take the consumer amenity variable values from the matched cities to be the IVs (Matchiv1, Matchiv2) for the city in question.

With "matched-city" instrumental variables, we then employ two-stage least squares (2SLS) to estimate model (1). The matching IV approach is used to tackle endogeneity problems caused by missing variables. Partridge et al. (2017) adopted this approach to construct instrumental variables when no proper instrument is available. Theoretically, valid instruments should satisfy two basic conditions: (1) relevance, i.e., the instruments should be highly correlated with the endogenous explanatory variable and (2) exogeneity-i.e., the instruments should be uncorrelated to the error term. In our case, the amenity values of the matched cities can be ideal instruments for amenities in the underlying city because the matched cities should have similar amenities, which fulfill the first condition. Secondly, the matched cities are at least $200 \mathrm{~km}$ far away, which means the second condition would be met because amenities for the matched cities are less likely to be correlated with shocks for the underlying city.

This hybrid of matching and IV approach has also been employed by some previous studies. For instance, Autor et al. (2013) use the contemporaneous composition and growth of Chinese imports in eight other developed countries to instrument for growth of Chinese imports to the USA. Likewise, Partridge et al. (2017) and Malgouyres (2017) use an identical approach to ours in deriving international trade instruments for local regions. To assess the robustness of our results, a series of sensitivity analyses will be conducted including the use of different estimation methods and matching instruments.

\section{Main results analysis}

Table 2 reports the OLS results by regressing model (1). Correspondingly, column (1) presents the results with only amenity variables, while columns (2)-(7) report the results where different control variables are added. Finally, columns (8)-(10) display the results where the individual amenity variables are replaced with the index amenity variables..

Table 2 shows that sunshine is significantly positively associated with innovation outcomes, while air pollutant is negatively associated with regional innovation. Also, for the natural amenity variables, only the sunshine and air quality variables

\footnotetext{
11 The Mahalanobis distance for prefecture-level cities $\mathrm{i}$ and $\mathrm{j}$ is defined as $M D=(x i-x j)^{\prime} C^{\wedge}-1(x i-x j)$, where $x$ is a vector of covariates and $C^{\wedge}$ is the estimated covariance matrix. The covariates are GDP per-capita, average years of schooling, population, and population density. By changing the covariates, more sensitivity results are reported in "Appendix".
} 
are significant. There is no significant evidence that the other climate amenities such as precipitation and humidity affect innovation. There is also no evidence that green amenities at the prefecture level have a statistically significant influence on innovation, which somewhat contrasts with Zheng et al.'s (2009) results. This implies that places with more sunshine have advantages for generating innovation. As such, it is reasonable to increasingly expect Chinese migration patterns to become more similar to that of the latter 1900s in the USA, when migration was strongly affected by climate (Graves 1980; Rappaport 2007).

Regarding each individual consumer amenity, only those related to healthcare services, educational resources, and public transportation have a significant effect. However, if there is collinearity among the amenity indicators, we should not exclude the possibility that the statistically insignificant amenity variables shown in columns (1)-(7) could still be significant determinants of regional innovation. ${ }^{12}$ Columns (8)-(10) report the results using principal components' natural amenity index and consumer amenity index that use all of the amenity variables in their construction. These results show a strong statistically positive relationship between the indexes and regional innovation.

When the control variables are added, the significance level for the main amenity variables (e.g., sunshine, air quality, healthcare resources, primary education resources, and public transportation) remains unchanged, though a few lose some of their statistical significance from 1 to $10 \%$ (e.g., primary education resources per capita) and two amenity variables totally lose significance in the last two columns (e.g., healthcare resources per capita, middle school resources per capita). In contrast, when single amenity variables are introduced one at a time along with the two amenity indexes (natural amenity index and consumer amenity index), the coefficients for the amenity indexes are positive and significant at the $1 \%$ level. Overall, the evidence suggests a strong positive correlation between amenities and innovation.

Apart from the role of amenities, several economic factors such as R\&D, human capital, population density, and economic wealth are also key drivers of Chinese innovation. Notably, while Crescenzi et al. (2012) found that R\&D and agglomeration economies are the main factors explaining provincial innovation growth, we highlight two other important engines for innovation growth based on the city-level data: human capital and economic wealth (GDP per capita). In addition, market size, proxied by population, is negatively associated with innovation, suggesting that population density is a better fit than simply using total city population. In general, amenities along with other drivers of innovation such as R\&D inputs, human capital, and agglomeration economies are all impetus of regional innovation, and likely all are necessary components for innovation. All these factors work together to shape the geography of innovation in China.

Table 3 reports the 2 SLS results in which consumer amenities are treated as endogenous using the matching IV strategy. Generally, we use nine indicators for consumer amenities, but the Durbin-Wu-Hausman test shows that only four are potentially endogenous (primary and middle schools per capita, number of beds, and

\footnotetext{
12 For example, the correlation coefficient between sunshine (avsun) and the temperature index (temindex) is 0.6 .
} 


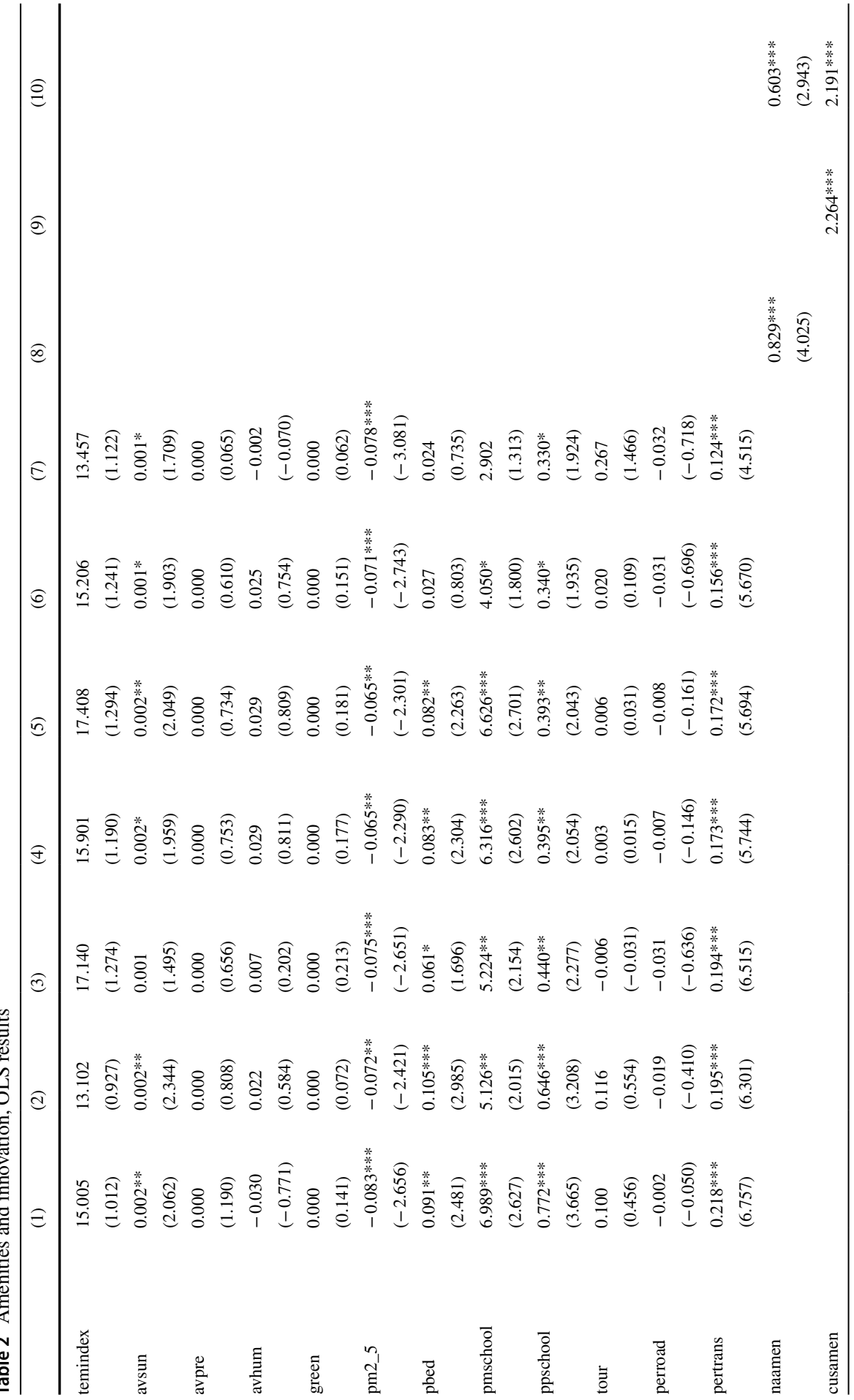




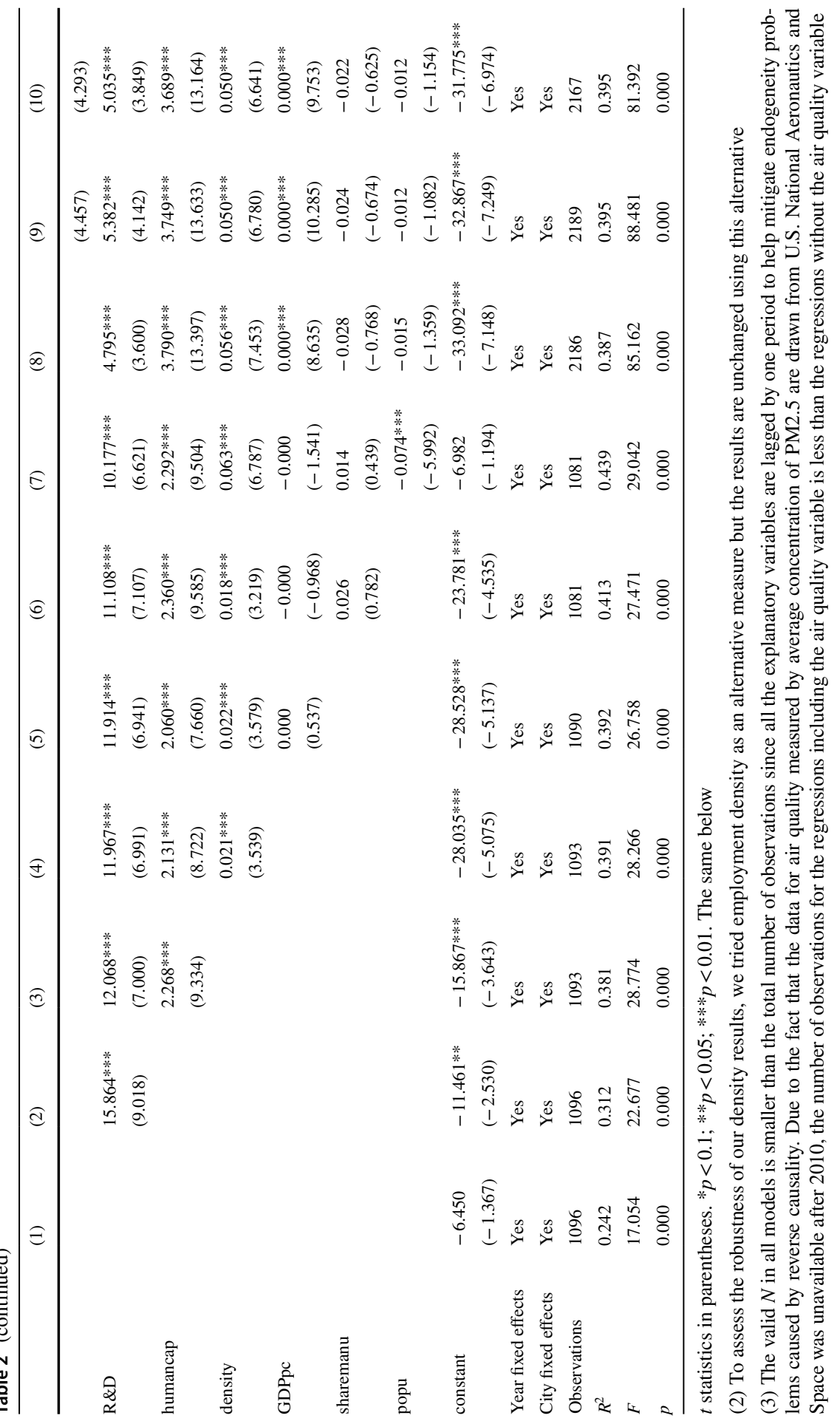


number of primary schools). Thus, we only report IV results for the regressions that appear to be endogenous. Specifically, columns (1) through (4) list the results where one of the four consumer amenity variables is individually added to the model. ${ }^{13}$ At the very bottom of Table 3, we report two diagnostic tests for the IV regressions including the first-stage F-statistic for the strength of the instruments and the overidentification test. Both tests indicate that the instruments are strong and pass the over identification tests, supporting their validity.

Local educational resources in primary and middle schools and healthcare resources remain salient factors in determining patenting innovation. This implies that patenting innovation is positively linked to a city's educational resources for primary and secondary school students. We believe one of the main reasons for this pattern is the type of highly educated workers critical to innovation are also parents who value educational quality for their children. Thus, while good primary and middle school resources will eventually produce more human capital, it appears to immediately attract highly educated workers interested in their children. Moreover, a pleasant natural environment is again found to be positively linked with local innovation, since the natural amenity index has a positive and significant and positive sign in all regressions. Apart from that, the significances and signs for the control variables are consistent with the original findings, which again confirm that the basic engines of innovation are R\&D, human capital, density, and a wealthy economy.

To assess the sensitivity of the IV results, we tried several different matching criteria to construct IV matches. Previously, four variables-GDP per-capita (GDPpc), average years of schooling ( avedu), agglomeration (рори), and density (density) from the initial year of analysis, 2007, were chosen to be covariates for identifying the matches for each prefecture city. We changed the matching criteria to using the same covariates but measured in an earlier period in 2003 to further reduce possible endogeneity (or reverse causality) concerns. ${ }^{14}$ At the same time, all the other criteria for the matching process remain the same. The new results are reported in the first four columns in Table 8 in "Appendix." Again, the primary and secondary school variables as well as healthcare services are all positively linked with innovation performance. Also, the results of corresponding first-stage F-statistics and the over-identification tests suggest the instruments are both strong and pass the exclusion criteria. Therefore, the impact of educational resources is robust to different matching instruments.

In further sensitivity analysis, we replace the matching covariates with GDP percapita, average years of schooling (avedu), agglomeration ( tion share between 25 and 49 years old (share2549). ${ }^{15}$ Using the instruments generated by the new matching criteria, we repeat the same 2SLS (see the results in the last four columns in Table 8 in "Appendix"). These results once more confirm the significant role of consumer amenities related to the educational resources and

\footnotetext{
13 To assess the degree of any potential multicollinearity problems, we conducted variance inflation factor (VIF) analysis between the main control variables and consumer amenity variables. Nevertheless, the results in Table A-3 in the appendix suggest that any multicollinearity is not severe.

14 We chose the year 2003 because the available data starts in 2003.

15 We select the labor-force share between 25 and 49 to proxy for the most creative part of the labor force. Nevertheless, using other population groupings did not alter our main results.
} 
Table 3 Matching IV results, consumer amenities

(1)

$175.776 * * *$

(4.761)

ppschool

$7.537 * * *$

(4.010)

bed

pschool

naamen

$0.726 * * *$

(2.688)

$R \& D$

0.470

(0.239)

humancap

$2.327 * * *$

(4.830)

density

$0.080^{* * *}$

(7.201)

GDPpc

$0.000 * * *$

(6.884)

sharemanu

$-0.139 * * *$

$(-2.585)$

popu

0.005

(0.308)

Year fixed effects

Yes

City fixed effects

Obs

Sargan test

Yes

2177

[0.533]

[0.000]

21.28

Durbin-Wu-Hausman test

First-stage $F$-statistics

$4.727 * * *$

(3.302)

$2.878^{* * * *}$

(7.580)

$0.054 * * *$

(6.585)

(7.522)

$-0.071 *$

$(-1.763)$

$-0.027^{* * *}$

$(-2.181)$
(2)

(3)

(4)

(3.850)

4.323***

(3.148)

$0.014 * * *$

(3.151)

$0.594 * * *$

(2.613)

$4.165^{* * * *}$

(2.971)

$4.189 * * *$

$3.108 * * *$

(13.023)

(8.496)

$0.055^{* * *}$

$0.052 * * *$

(7.192)

(6.586)

0.000 ***

$0.000 * * *$

(8.537)

(7.507)

$-0.031$

-0.069 *

$(-0.852)$

$(-1.747)$

$-0.004$

0.010

$(-0.344)$

(0.680)

Yes

Yes

2182

2174

[0.138]

[0.081]

[0.012]

36.81

(1) $t$ statistics in parentheses. ${ }^{*} p<0.1 ; * * p<0.05 ; * * * p<0.01$

(2) Sargan test and Durbin-Wu-Hausman test report the $p$ values in the square brackets

(3) Only the results which the Durbin-Wu-Hausman test did not reject the hypothesis of endogeneity are reported

(4) Valid instruments should satisfy the two basic conditions: (1) exogeneity, i.e., the instruments should be uncorrelated with the error term, meaning the Sargan test should reject its null hypothesis; (2) relevance, i.e., the instruments should be correlated with the endogenous explanatory variable, meaning the first-stage $F$-statistic will be large enough to reject the null hypothesis that the two instrument coefficients are jointly zero (values $>10$ suggest strong instruments)

healthcare resources in affecting innovation. Overall, the sensitivity tests show that consumer amenities play a robust role in affecting innovation regardless of the estimation strategy.

In summary, the empirical results ascertain that local natural amenities and consumer amenities play a significant role in shaping the geography of regional 
innovation. Specifically, natural amenities including temperature, sunshine, air quality, and resources for primary and middle school students have a statistically significant impact on local innovation.

\section{Mechanism analysis}

In Sect. 3, we assume that amenities are associated with local innovation systems through two key mechanisms (1) by attracting more skilled workers and (2) by improving the productivity of local workers. To test the first mechanism, we now regress the stock of human capital on amenities and the other controls and report the results in Table 4. Amenities are significantly positively associated with human capital, regardless whether amenities are measured by a single indicator or the comprehensive consumer amenity index or natural amenity index. This pattern supports the first proposed mechanism.

Regarding the productivity mechanism, due to the heterogeneity of personal productivity and data limitations, we instead indirectly consider this mechanism to appraise whether the productivity mechanism works in explaining the positive impact of amenities on innovation. Simply put, when human capital and amenities are both included in the innovation model, the human capital variable controls for that effect and if the amenity variable coefficients are significant, then this amenity effect can be attributed to some other mechanism besides human capital. Given that the focus of the literature has been on the productivity mechanism, we believe the most likely mechanism is through productivity. ${ }^{16}$ Unfortunately, we lack micro-level data to further assess the mechanisms, though our results are suggestive.

\section{Amenities, city characteristics, and innovation}

The initial hedonic literature assumed workers are homogeneous in tastes and skill (Roback 1982). However, valuations for amenities can differ across income and skill levels, as posited by Roback (1988). One reason is the hierarchy of needs theory (Maslow 1943, 1954), which posits that when people can satisfy their basic needs such as food and shelter, they will then strive to meet higher-level needs such as aesthetic needs and higher quality of life. For example, scale-related urban amenities, which is defined as clusters of retail stores and cultural amenities made possible by the urban concentration of cinemas, theaters, museums, etc. (Dalmazzo and

\footnotetext{
${ }^{16}$ Using individual-level data would further help our assessment of the underlying mechanisms, but this evidence is a good start. Additionally, to better test the assumption that there is both direct and indirect impacts of amenities on innovation (where the direct impact refers to the positive impact of amenities on workforce productivity while the indirect impact refers to the impact of amenities on attracting human capital), we tried further simultaneous equations models (Seemingly Unrelated Regressions, Three-stage Regressions) to identify the causal mechanisms. As expected, those regression results show that both natural and consumer amenities have significant and positive impacts on local human capital, further augmenting our findings (results available on request to the authors).
} 
Table 4 Mechanism analysis; OLS results

\begin{tabular}{|c|c|c|c|c|c|}
\hline \multirow[b]{3}{*}{ Dependent variable } & \multirow{2}{*}{$\begin{array}{l}\text { (1) } \\
\text { Fixed effects }\end{array}$} & \multirow{2}{*}{$\begin{array}{l}\text { (2) } \\
\text { Random effects }\end{array}$} & \multirow{2}{*}{$\begin{array}{l}(3) \\
\text { Fixed effects }\end{array}$} & \multirow{2}{*}{$\begin{array}{l}(4) \\
\text { Fixed effects }\end{array}$} & \multirow{2}{*}{$\begin{array}{l}(5) \\
\text { Fixed effects }\end{array}$} \\
\hline & & & & & \\
\hline & human capital & human capital & human capital & human capital & human capital \\
\hline \multirow[t]{2}{*}{ temindex } & -0.762 & -0.623 & & & \\
\hline & $(-0.421)$ & $(-0.328)$ & & & \\
\hline \multirow[t]{2}{*}{ avsun } & $0.000^{* * * *}$ & $0.001 * * *$ & & & \\
\hline & $(3.968)$ & $(4.667)$ & & & \\
\hline \multirow[t]{2}{*}{ avpre } & 0.000 & 0.000 & & & \\
\hline & $(0.463)$ & $(0.485)$ & & & \\
\hline \multirow[t]{2}{*}{ avhum } & 0.002 & 0.004 & & & \\
\hline & $(0.407)$ & $(0.852)$ & & & \\
\hline \multirow[t]{2}{*}{ green } & -0.000 & -0.000 & & & \\
\hline & $(-0.272)$ & $(-0.120)$ & & & \\
\hline \multirow[t]{2}{*}{ pm2_5 } & 0.001 & -0.003 & & & \\
\hline & $(0.387)$ & $(-0.765)$ & & & \\
\hline \multirow[t]{2}{*}{ pbed } & $0.021 * * *$ & $0.037 * * *$ & & & \\
\hline & $(4.218)$ & $(7.559)$ & & & \\
\hline \multirow[t]{2}{*}{ pmschool } & $0.768^{* *}$ & $0.701^{* *}$ & & & \\
\hline & $(2.315)$ & $(2.045)$ & & & \\
\hline \multirow[t]{2}{*}{ ppschool } & $0.076^{* * * *}$ & $0.069 * *$ & & & \\
\hline & $(2.955)$ & $(2.567)$ & & & \\
\hline \multirow[t]{2}{*}{ tour } & $0.069^{* *}$ & $0.184 * * *$ & & & \\
\hline & $(2.531)$ & $(8.720)$ & & & \\
\hline \multirow[t]{2}{*}{ perroad } & $0.012 *$ & 0.008 & & & \\
\hline & (1.767) & (1.125) & & & \\
\hline \multirow[t]{2}{*}{ pertrans } & -0.005 & 0.002 & & & \\
\hline & $(-1.101)$ & $(0.452)$ & & & \\
\hline \multirow[t]{2}{*}{ naamen } & & & $0.073^{* * *} *$ & & $0.067 * * *$ \\
\hline & & & $(4.406)$ & & $(3.981)$ \\
\hline \multirow[t]{2}{*}{ cusamen } & & & & $0.105^{* *}$ & $0.093 * *$ \\
\hline & & & & $(2.475)$ & $(2.218)$ \\
\hline \multirow[t]{2}{*}{ GDPpc } & $0.000^{* * * *}$ & $0.000 * * *$ & $0.000^{* * *} *$ & $0.000^{* * *}$ & $0.000 * * *$ \\
\hline & (13.218) & (15.113) & $(16.284)$ & (18.104) & $(16.642)$ \\
\hline \multirow[t]{2}{*}{ density } & $0.006^{* * * *}$ & $0.003 * * *$ & -0.001 & -0.001 & -0.001 \\
\hline & $(4.501)$ & $(6.445)$ & $(-1.146)$ & $(-1.287)$ & $(-1.300)$ \\
\hline \multirow[t]{2}{*}{ sharemanu } & $-0.009 *$ & -0.004 & $-0.026^{* * *}$ & $-0.026^{* * *}$ & $-0.025^{* * *}$ \\
\hline & $(-1.740)$ & $(-0.863)$ & $(-9.114)$ & $(-8.937)$ & $(-8.703)$ \\
\hline \multirow[t]{2}{*}{ popu } & $-0.004^{*}$ & -0.000 & $0.007 * * *$ & $0.007 * * *$ & $0.007 * * *$ \\
\hline & $(-1.895)$ & $(-0.270)$ & $(8.282)$ & & \\
\hline constant & 0.122 & $-1.436^{* *}$ & $2.151^{* * * *}$ & $2.121^{* * *}$ & $2.135 * * *$ \\
\hline & $(0.139)$ & $(-2.069)$ & $(5.767)$ & $(5.646)$ & $(5.731)$ \\
\hline Year fixed effects & Yes & Yes & Yes & Yes & Yes \\
\hline City fixed effects & Yes & Yes & Yes & Yes & Yes \\
\hline Observations & 1081 & 1081 & 2187 & 2190 & 2168 \\
\hline
\end{tabular}


Table 4 (continued)

\begin{tabular}{llllll}
\hline & $(1)$ & $(2)$ & $(3)$ & $(4)$ & $(5)$ \\
& Fixed effects & Random effects & Fixed effects & Fixed effects & Fixed effects \\
Dependent variable & human capital & human capital & human capital & human capital & human capital \\
\hline$R^{2}$ & 0.738 & & 0.718 & 0.721 & 0.720 \\
$F$ & 116.141 & & 401.118 & 408.538 & 371.700 \\
$p$ & 0.000 & 0.000 & 0.000 & 0.000 & 0.000 \\
\hline
\end{tabular}

$t$ statistics in parentheses

$* p<0.1 ; * * p<0.05 ; * * * p<0.01$

de Blasio 2011), are found to be especially consumed by wealthier households and more educated workers (Glaeser et al. 2001; Dalmazzo and de Blasio 2011; Dorfman et al.,2011; Stephens and Partridge 2015). These amenity valuations may also differ across cities because of different income and skill levels, which may lead to some interesting interaction effects. Obviously, this question extends from exploring individual differences to city differences. To provide a framework for answering this question, we assess the following four hypotheses:

(1) Income heterogeneity effects-greater impact for more developed economies

People tend to have an increasing willingness to pay for amenities as their income increases. If wealthy people value amenities more (Adamson et al. 2004; Chen and Rosenthal 2008), the aggregated influence of amenities should rise with city income or wealth. For example, using city-level data, Zheng (2016) finds that there is significant income heterogeneity in the estimated marginal willingness to pay for city amenities, consistent with the hypothesis that amenities are expected to be more important as economies develop.

(2) Skill heterogeneity effects-larger impacts in cities with more human capital

The impact of amenities may also vary by human capital level. If amenities are more attractive for more educated individuals, cities with higher shares of educated workers should be more influenced by amenities. Indeed, Dorfman et al. (2011) found amenities have a significant effect on high-technology job growth, and the share of university graduates located in high-amenity US coastal areas has also significantly increased since 2000 (Stephens and Partridge 2015). Then, it is reasonable to presume that cities with more human capital are influenced more by amenities.

(3) Size heterogeneity effects — greater impact for larger cities

A city's population in spatial equilibrium may have been greatly shaped by amenities (Tiebout 1956; Rappaport 2007), which means that the city's population could capture the majority of the variation in cost of living for which amenities have been 
capitalized. For example, Partridge et al. (2008) argue that higher-ordered consumer services increasingly exist in successively larger cities. Thus, cities with a larger population would also have been affected more by amenity levels.

(4) Density heterogeneity effects-greater impact for denser economies

Density itself could be a kind of amenity. For example, Florida (2002b) claims that creative-class workers are attracted to concentrations of creative people. Besides, knowledge for innovation is transferred more easily in denser places (Betz et al. 2016). Consequently, we expect that the impact of amenities is greater in denser economies.

To examine the above hypotheses, we construct interaction terms between the amenity variables and one of the city characteristic variables. The resulting models are specified as follows:

$$
\begin{gathered}
\text { no }_{i, t}=\gamma+\beta_{1} \text { amenity }_{i, t-1}+\beta_{2} X_{i, t-1}+\kappa_{1} \text { GDPpc } * \text { amenity }+\mu_{i}+v_{t}+\varepsilon_{i t} . \\
\text { inno }_{i, t}=\gamma+\beta_{1} \text { amenity }_{i, t-1}+\beta_{2} X_{i, t-1}+\kappa_{2} \text { humancap } * \text { amenity }+\mu_{i}+v_{t}+\varepsilon_{i t} . \\
\text { inno }_{i, t}=\gamma+\beta_{1} \text { amenity }_{i, t-1}+\beta_{2} X_{i, t-1}+\kappa_{3} \text { popu } * \text { amenity }+\mu_{i}+v_{t}+\varepsilon_{i t} . \\
\text { inno }_{i, t}=\gamma+\beta_{1} \text { amenity }_{i, t-1}+\beta_{2} X_{i, t-1}+\kappa_{4} \text { density } * \text { amenity }+\mu_{i}+v_{t}+\varepsilon_{i t} .
\end{gathered}
$$

where $\quad$ GDPpc $*$ amenity,humancap $*$ amenity, $\quad$ popu $*$ amenity, and density $*$ amenity are the interaction variables described above. Correspondingly, by examining the interaction coefficients, i.e., $\boldsymbol{\kappa}_{1} ., \boldsymbol{\kappa}_{2} ., \boldsymbol{\kappa}_{3}, \boldsymbol{\kappa}_{4}$, we appraise whether the marginal influence of amenities varies with specific city characteristics. To simplify the interpretation, we use the amenity index variables described above rather than the individual amenity variables (natural amenity index and consumer amenity index) in these models. All of the interaction coefficients in models (3), (4), and (6) are significant with the exceptions of the interaction term between consumer amenity index and human capital in model (4) and the interaction term in model (5). Hence, these results further support hypotheses (1), (2), and (4)-i.e., the positive impact of amenities on regional innovation is greater in larger, more developed cities and in cities with a critical mass of highly educated workers.

To interpret the interaction effects better, Fig. 2 shows both the baseline and the marginal effects. The positive interaction term between amenity index and GDP per capita indicates that the marginal impact of amenities on innovation increases with GDP per capita (see figures a.1 and a.2). The same applies for population density in that both natural amenities and consumer amenities have a larger marginal influence on innovation as density increases (see figures c.1 and c.2). Likewise, the marginal influence of amenities is positively linked to increases in the city human capital (see figure b).

Therefore, our findings support the hypotheses that the impact of amenities is placebased but that their influence is also heterogeneous depending on the city's level of development. 


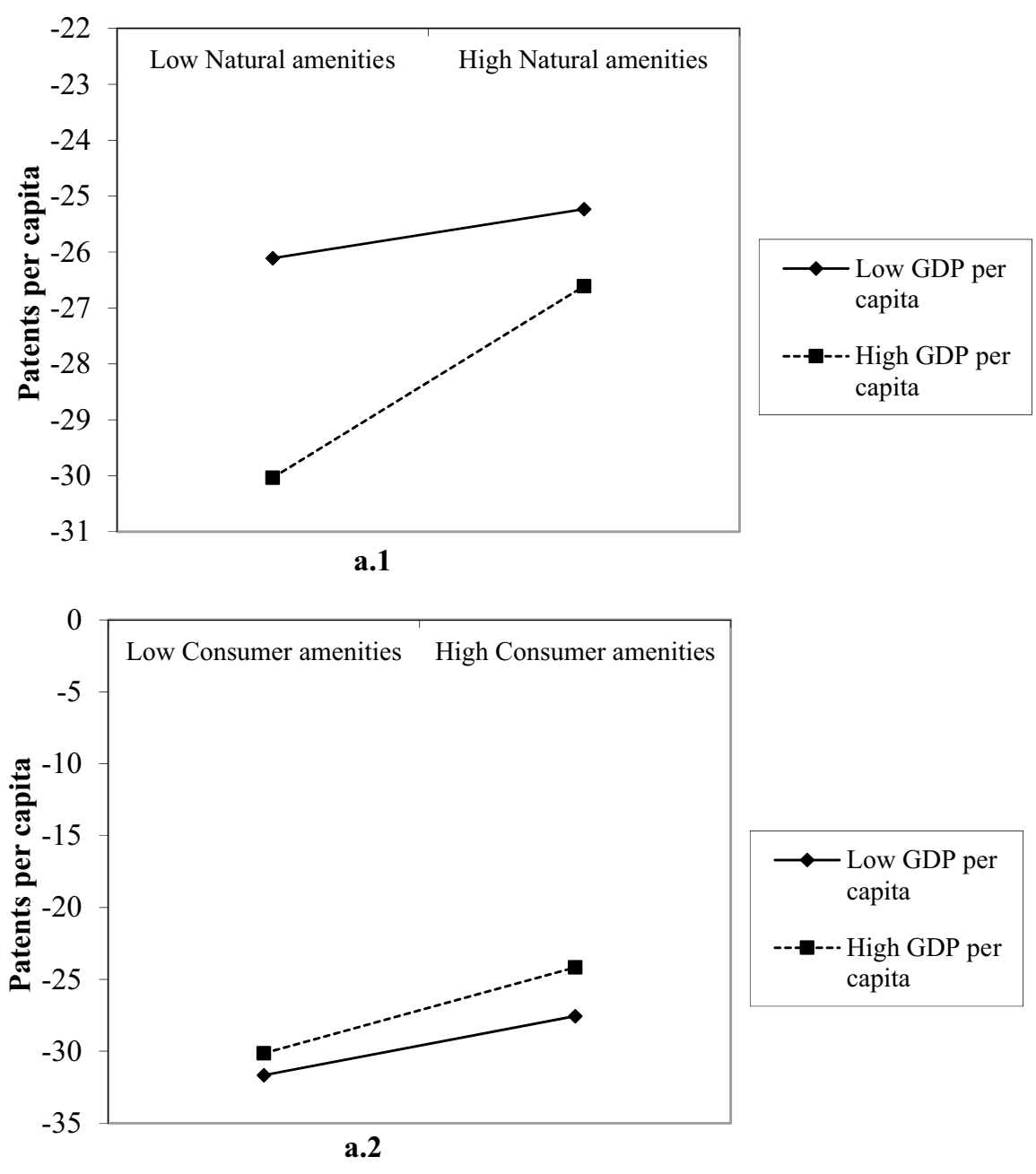

a interaction between ec onomic wealth and amenities

Fig. 2 Interpreting the interaction terms

\section{Conclusion and policy implications}

This paper focused on the role of amenities in affecting innovation, which has been largely under-explored in the literature. The empirical results suggest that particular amenities such as air quality, sunshine, public transportation, and educational resources can contribute to city-level differences in Chinese innovation. The findings are robust to different estimation methods and instrumental variable strategies. Therefore, even though China is a developing country, our findings suggest that quality-of-life factors can play a key role, just as in developed countries. Moreover, our results suggest that amenities are associated with local innovation systems 


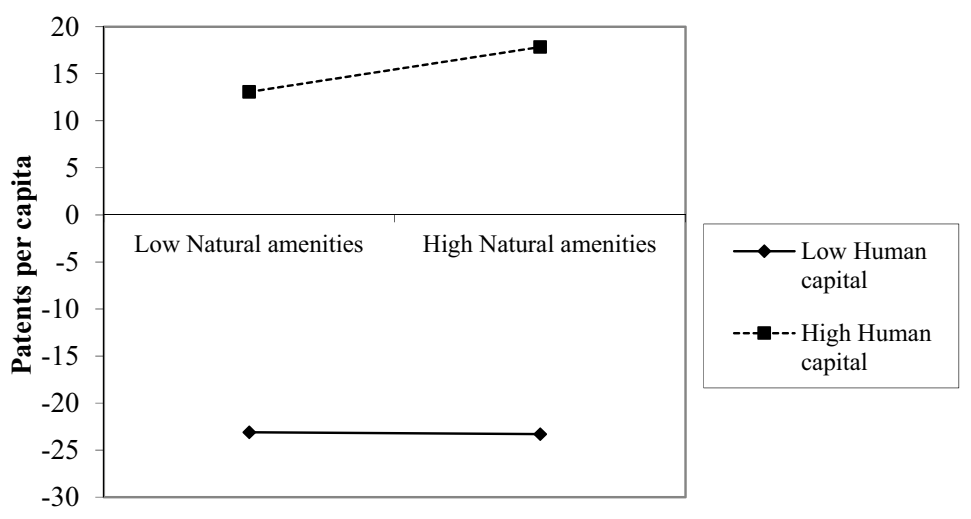

b interaction between human capital and amenities
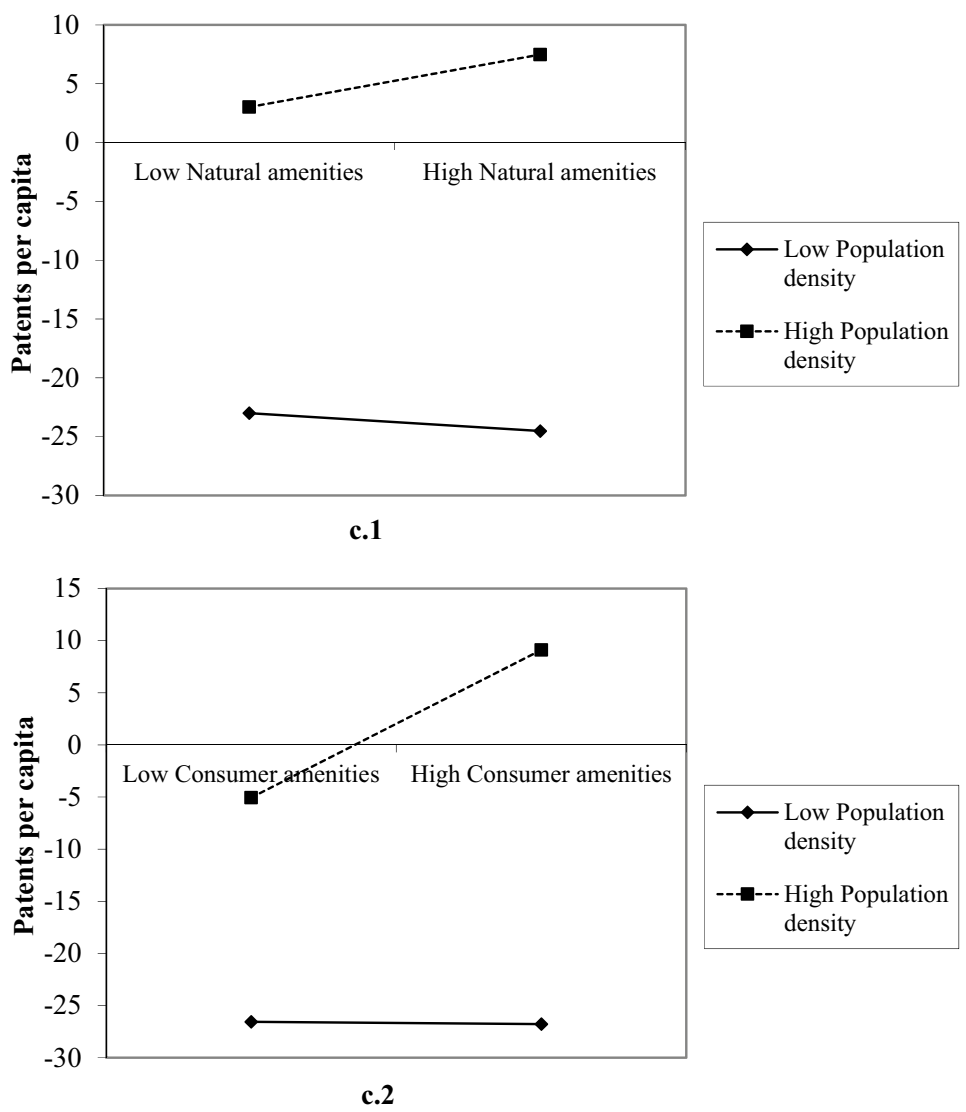

c interaction between popula tion density and amenities

Fig. 2 (continued) 
through two key mechanisms-i.e., by attracting more skilled workers and by improving the productivity of local workers. As income grows and workers place more value on quality of life, we predict a further strengthening of the link between amenities and Chinese regional innovation over time. Thus, providing quality amenities appears to be a good policy to promote place-specific innovation (Boschma and Fritsch 2009; Florida 2014; Lehmann and Seitz 2017).

Generally, this paper finds that amenities along with other drivers of innovation such as R\&D inputs, stock of human capital, and agglomeration economies are all the impetus of regional innovation, and their effects interact with one another. In particular, while agglomeration economies and amenities are not direct inputs in knowledge creation, they appear to stimulate the input-output efficiency in its creation. All these factors work together to shape the geography of patenting innovation in China. Meanwhile, among all considered amenity factors, only amenities related to clean air, sunshine, public transportation, public educational and healthcare services are found to statistically affect city-level differences in Chinese innovation from 2007 to 2014. The impact of amenities also varies with city characteristics such as the economic wealth, density, and human capital, in which these effects also vary by amenity type. Specifically, the positive impact of amenities on regional innovation is greater in larger, wealthier cities and in cities with a critical mass of highly educated workers.

As China aims to achieve a twenty-first-century innovation-oriented economy, understanding the drivers of local innovation is a key policy priority. This study reveals a significant impetus of regional innovation in China is amenities. Just as Glaeser et al. (2001) suggests the benefits of consumer cities in the USA, our findings suggest the benefits of amenities in terms of regional innovation, which are typically not considered in innovation policies.

Second, differentiated amenity-related strategies or city-based policies are recommended for innovation development. For instance, for relatively developed cities, the role of amenities should receive more emphasis, as the influence of amenities on innovation is larger in these areas. Also, reducing city disamenity factors such as air pollution appears to also promote local innovation. In contrast, the policies for innovation development for poorer, less developed cities should focus on other fundamental drivers of innovatione.g., R\&D and human capital investment. However, even lagging cities that are well endowed with natural amenities can better utilize their assets to attract innovative workers.

Finally, this paper has some limitations that merit further research. First, more proxy measures of innovation should be considered to assess whether the results are robust. For example, using patents to proxy for innovation does not consider innovations that are not patented, and it fails to reflect the extent to which innovations are successfully commercialized (Crescenzi et al. 2012). Second, due to data availability, this paper did not directly test the underlying mechanisms by examining how individual migration decisions are affected by amenities. Instead, the results confirm a positive association between skills and amenities that is consistent with that proposition, though we did incorporate instrumental variable approaches that increase our confidence. Yet, these limitations provide potential directions for future research once more micro-level data become available.

Acknowledgements We acknowledge that this work has been supported by National Natural Science Foundation of China (71573230) and Social Science Fund of Zhejiang Province (17NDJC191YB). 
Open Access This article is licensed under a Creative Commons Attribution 4.0 International License, which permits use, sharing, adaptation, distribution and reproduction in any medium or format, as long as you give appropriate credit to the original author(s) and the source, provide a link to the Creative Commons licence, and indicate if changes were made. The images or other third party material in this article are included in the article's Creative Commons licence, unless indicated otherwise in a credit line to the material. If material is not included in the article's Creative Commons licence and your intended use is not permitted by statutory regulation or exceeds the permitted use, you will need to obtain permission directly from the copyright holder. To view a copy of this licence, visit http://creativecommons.org/licenses/by/4.0/.

\section{Appendix}

See Tables 5, 6, 7, 8, and 9 .

Table 5 Test results for the principal component analysis

\begin{tabular}{|c|c|c|c|}
\hline Component & Eigenvalue & Difference(\%) & Cumulative(\%) \\
\hline \multicolumn{4}{|c|}{ Principal component analysis: eigenanalysis of the correlation matrix (natural amenities) } \\
\hline Comp1 & 2.767 & 46.117 & 46.117 \\
\hline Comp2 & 1.247 & 20.775 & 66.892 \\
\hline Comp3 & 0.976 & 16.265 & 83.157 \\
\hline Comp4 & 0.503 & 8.383 & 91.541 \\
\hline Comp5 & 0.310 & 5.175 & 96.715 \\
\hline Comp6 & 0.197 & 3.285 & 100.000 \\
\hline \multicolumn{3}{|l|}{ Variable } & Comp1 \\
\hline \multicolumn{4}{|c|}{ Principal component analysis: principal components' coefficients(natural amenities) } \\
\hline \multicolumn{3}{|l|}{ temindex } & 0.301 \\
\hline \multicolumn{3}{|l|}{ avsun } & 0.237 \\
\hline \multicolumn{3}{|l|}{ avhum } & 0.160 \\
\hline \multicolumn{3}{|l|}{ avpre } & 0.124 \\
\hline \multicolumn{3}{|l|}{ green } & 0.376 \\
\hline \multicolumn{3}{|l|}{$\mathrm{pm} 2.5$} & -0.688 \\
\hline
\end{tabular}

\begin{tabular}{|c|c|c|c|}
\hline Component & Eigenvalue & Difference $(\%)$ & Cumulative(\%) \\
\hline \multicolumn{4}{|c|}{ Principal component analysis: eigenanalysis of the correlation matrix (consumer amenities) } \\
\hline Comp1 & 2.553 & 42.556 & 42.556 \\
\hline Comp2 & 1.553 & 25.886 & 68.442 \\
\hline Variable & & & Comp1 \\
\hline \multicolumn{4}{|c|}{ Principal component analysis: principal components' coefficients(consumer amenities) } \\
\hline rbed & & & 0.048 \\
\hline rmschool & & & 0.088 \\
\hline rpschool & & & 0.580 \\
\hline ttour & & & 0.519 \\
\hline pertrans & & & 0.149 \\
\hline perroad & & & 0.038 \\
\hline
\end{tabular}

We pick up Comp1 to be the amenity indexes for natural amenities and consumer amenities (naamen, cusamen), respectively 
Table 6 Descriptive statistics for the main variables

\begin{tabular}{|c|c|c|c|c|c|}
\hline Variable & Obs & Mean & SD & Min & $\operatorname{Max}$ \\
\hline inno & 2248 & 6.931 & 17.644 & 0.009 & 214.290 \\
\hline temindex & 2231 & 18.618 & 5.127 & 6.172 & 32.461 \\
\hline pm2_5 & 1124 & 50.772 & 23.833 & 5.996 & 108.339 \\
\hline avsun & 2248 & 1900.374 & 464.907 & 598.400 & 2830.600 \\
\hline avpre & 2248 & 1003.498 & 812.802 & 148.800 & 9364.000 \\
\hline avhum & 2248 & 66.460 & 9.498 & 42.000 & 85.000 \\
\hline green & 2242 & 944.308 & 1522.404 & 2.059 & 63855.180 \\
\hline pbed & 2243 & 36.803 & 15.201 & 9.773 & 135.810 \\
\hline pmschool & 2245 & 0.534 & 0.138 & 0.222 & 1.358 \\
\hline ppschool & 2246 & 1.950 & 1.259 & 0.199 & 12.348 \\
\hline tour & 2248 & 4.549 & 6.133 & 0.000 & 83.000 \\
\hline perroad & 2237 & 10.948 & 7.433 & 0.310 & 108.370 \\
\hline pertrans & 2242 & 7.475 & 6.564 & 0.320 & 110.520 \\
\hline pbed & 2243 & $15,729.530$ & $14,044.940$ & 1055.000 & $148,715.000$ \\
\hline mschool & 2245 & 222.854 & 140.083 & 11.000 & 1361.000 \\
\hline pschool & 2246 & 812.971 & 707.591 & 18.000 & 7990.000 \\
\hline naamen & 2225 & 0.000 & 0.998 & -3.794 & 11.037 \\
\hline cusamen & 2228 & 0.000 & 0.998 & -3.008 & 6.234 \\
\hline $\mathrm{R} \& \mathrm{D}$ & 2246 & 0.203 & 0.185 & 0.013 & 4.147 \\
\hline GDPpc & 2244 & $36,289.660$ & $28,870.220$ & 99.000 & $467,749.000$ \\
\hline popu & 2248 & 440.203 & 308.776 & 18.140 & 3375.200 \\
\hline density & 2248 & 432.063 & 327.924 & 4.820 & 2648.110 \\
\hline sharemanu & 2220 & 44.365 & 13.850 & 4.450 & 84.400 \\
\hline humancap & 2241 & 5.436 & 4.639 & 0.606 & 36.314 \\
\hline avedu & 2248 & 9.030 & 0.856 & 6.447 & 12.894 \\
\hline
\end{tabular}


Table 7 Variance inflation factor (VIF) test results

\begin{tabular}{|c|c|c|c|c|c|c|c|c|}
\hline \multicolumn{3}{|l|}{ Test 1} & \multicolumn{3}{|l|}{ Test 2} & \multicolumn{3}{|l|}{ Test 3} \\
\hline Variable & VIF & $1 / \mathrm{VIF}$ & Variable & VIF & $1 / \mathrm{VIF}$ & Variable & VIF & $1 / \mathrm{VIF}$ \\
\hline pbed & 2.66 & 0.375713 & GDPpc & 2.13 & 0.469087 & GDPpc & 2.19 & 0.457198 \\
\hline GDPpc & 2.44 & 0.410448 & _It_2013 & 1.96 & 0.509322 & _It_2013 & 1.93 & 0.519069 \\
\hline humancap & 2.33 & 0.428919 & _It_2012 & 1.87 & 0.533542 & _It_2012 & 1.85 & 0.541948 \\
\hline _It_2013 & 1.95 & 0.514028 & _It_2011 & 1.81 & 0.551716 & humancap & 1.82 & 0.550929 \\
\hline _It_2012 & 1.85 & 0.541704 & humancap & 1.81 & 0.552085 & _It_2011 & 1.79 & 0.557578 \\
\hline _It_2011 & 1.78 & 0.561817 & _It_2010 & 1.77 & 0.56521 & _It_2010 & 1.76 & 0.568827 \\
\hline _It_2010 & 1.75 & 0.572961 & _It_2009 & 1.73 & 0.577322 & _It_2009 & 1.73 & 0.579126 \\
\hline _It_2009 & 1.72 & 0.580462 & _It_2008 & 1.72 & 0.582587 & _It_2008 & 1.71 & 0.583369 \\
\hline _It_2008 & 1.72 & 0.582903 & density & 1.47 & 0.679289 & density & 1.48 & 0.677355 \\
\hline density & 1.48 & 0.674047 & $\mathrm{R} \& \mathrm{D}$ & 1.43 & 0.698876 & sharemanu & 1.43 & 0.698009 \\
\hline R\&D & 1.41 & 0.711516 & sharemanu & 1.4 & 0.713081 & $\mathrm{R} \& \mathrm{D}$ & 1.4 & 0.71226 \\
\hline sharemanu & 1.4 & 0.713343 & popu & 1.34 & 0.745356 & ppschool & 1.36 & $\mathbf{0 . 7 3 7 3 5 2}$ \\
\hline popu & 1.3 & 0.768416 & pmschool & 1.24 & 0.809375 & popu & 1.26 & 0.792794 \\
\hline Mean VIF & 1.83 & & Mean VIF & 1.67 & & Mean VIF & 1.67 & \\
\hline \multicolumn{3}{|l|}{ Test 4} & \multicolumn{3}{|l|}{ Test 5} & \multicolumn{3}{|l|}{ Test 6} \\
\hline Variable & VIF & $1 / \mathrm{VIF}$ & Variable & VIF & $1 / \mathrm{VIF}$ & Variable & VIF & $1 / \mathrm{VIF}$ \\
\hline bed & 6.77 & 0.147801 & popu & 7.42 & 0.134696 & popu & 2.89 & 0.345753 \\
\hline popu & 4.84 & 0.20643 & mschool & 7.42 & 0.134716 & pschool & 2.76 & 0.36188 \\
\hline humancapital & 2.58 & 0.387343 & GDPpc & 2.14 & 0.467604 & GDPpc & 2.16 & 0.462607 \\
\hline GDPpc & 2.18 & 0.458169 & _It_2013 & 1.94 & 0.514638 & _It_2013 & 1.92 & 0.521489 \\
\hline _It_2013 & 1.93 & 0.519212 & _It_2012 & 1.86 & 0.536906 & humancap & 1.85 & 0.540848 \\
\hline _It_2012 & 1.83 & 0.547357 & humancap & 1.82 & 0.549313 & _It_2012 & 1.84 & 0.544736 \\
\hline _It_2011 & 1.77 & 0.56375 & _It_2011 & 1.8 & 0.554372 & _It_2011 & 1.79 & 0.559641 \\
\hline _It_2010 & 1.74 & 0.574403 & _It_2010 & 1.76 & 0.566665 & _It_2010 & 1.75 & 0.570675 \\
\hline _It_2009 & 1.72 & 0.58154 & _It_2009 & 1.73 & 0.578411 & _It_2009 & 1.72 & 0.580486 \\
\hline _It_2008 & 1.72 & 0.582955 & _It_2008 & 1.72 & 0.582807 & _It_2008 & 1.71 & 0.583545 \\
\hline R\&D & 1.47 & 0.680684 & density & 1.46 & 0.686564 & density & 1.48 & 0.673759 \\
\hline density & 1.45 & 0.687534 & R\&D & 1.41 & 0.707206 & R\&D & 1.42 & 0.702957 \\
\hline sharemanu & 1.38 & 0.725625 & sharemanu & 1.4 & 0.71223 & sharemanu & 1.41 & 0.710968 \\
\hline Mean VIF & 2.41 & & Mean VIF & 2.61 & & Mean VIF & 1.9 & \\
\hline
\end{tabular}

VIF test reports the variance inflation factors for the independent variables. VIF $>10$ suggests severe multicollinearity problems 
Table 8 Matching IV results, changing matching criteria

(1)

(2)

(3)

(4)

(5)

(6)

(7)

$(8)$

Robustness test 1

Robustness test 2

\begin{tabular}{|c|c|c|c|c|c|c|c|c|}
\hline \multirow{2}{*}{$\begin{array}{l}\text { pmschool } \\
\text { ppschool }\end{array}$} & $\begin{array}{l}16.132 * * \\
(2.484)\end{array}$ & & & & $\begin{array}{l}51.598^{*} \\
(1.686)\end{array}$ & & & \\
\hline & & $\begin{array}{l}3.259^{*} \\
(1.707)\end{array}$ & & & & $\begin{array}{l}9.516^{*} \\
(1.687)\end{array}$ & & \\
\hline bed & & & $\begin{array}{l}0.000^{*} \\
(1.841)\end{array}$ & & & & $\begin{array}{l}0.000^{* *} \\
(2.544)\end{array}$ & \\
\hline pschool & & & & $\begin{array}{l}0.015 \\
(1.598)\end{array}$ & & & & $\begin{array}{l}0.522 \\
(0.250)\end{array}$ \\
\hline naamen & $\begin{array}{l}0.814 * * * \\
(3.937)\end{array}$ & $\begin{array}{l}0.954 * * * \\
(4.077)\end{array}$ & $\begin{array}{l}0.822 * * * \\
(3.958)\end{array}$ & $\begin{array}{l}1.075 * * * \\
(3.891)\end{array}$ & $\begin{array}{l}0.789 * * * \\
(3.774)\end{array}$ & $\begin{array}{l}0.465 \\
(1.464)\end{array}$ & $\begin{array}{l}0.817 * * * \\
(3.893)\end{array}$ & $\begin{array}{l}7.636^{* *} \\
(2.225)\end{array}$ \\
\hline $\mathrm{R} \& \mathrm{D}$ & $\begin{array}{l}4.432 * * * \\
(2.871)\end{array}$ & $\begin{array}{l}4.818 * * * \\
(3.439)\end{array}$ & $\begin{array}{l}4.665^{* * * *} \\
(3.447)\end{array}$ & $\begin{array}{l}5.445 * * * \\
(3.536)\end{array}$ & $\begin{array}{l}3.546^{* *} \\
(2.273)\end{array}$ & $\begin{array}{l}4.703 * * * \\
(3.111)\end{array}$ & $\begin{array}{l}4.346 * * * \\
(3.181)\end{array}$ & $\begin{array}{l}17.875^{* * * *} \\
(3.193)\end{array}$ \\
\hline humancap & $\begin{array}{l}3.692 * * * \\
(9.695)\end{array}$ & $\begin{array}{l}4.185^{* * *} \\
(10.236)\end{array}$ & $\begin{array}{l}3.920 * * * \\
(12.458)\end{array}$ & $\begin{array}{l}4.504 * * * \\
(8.237)\end{array}$ & $\begin{array}{l}3.398 * * * \\
(8.860)\end{array}$ & $\begin{array}{l}2.638 * * * \\
(3.495)\end{array}$ & $\begin{array}{l}4.171 * * * \\
(13.138)\end{array}$ & $\begin{array}{l}20.825^{* * * *} \\
(3.212)\end{array}$ \\
\hline density & $\begin{array}{l}0.059 * * * \\
(6.566)\end{array}$ & $\begin{array}{l}0.057 * * * \\
(7.196)\end{array}$ & $\begin{array}{l}0.056^{* * *} \\
(7.371)\end{array}$ & $\begin{array}{l}0.060 * * * \\
(6.866)\end{array}$ & $\begin{array}{l}0.064 * * * \\
(7.153)\end{array}$ & $\begin{array}{l}0.053 * * * \\
(6.015)\end{array}$ & $\begin{array}{l}0.055^{* * *} \\
(7.209)\end{array}$ & $\begin{array}{l}0.083 * * * \\
(5.147)\end{array}$ \\
\hline GDPpc & $\begin{array}{l}0.000 * * * \\
(8.667)\end{array}$ & $\begin{array}{l}0.000 * * * \\
(8.330)\end{array}$ & $\begin{array}{l}0.000 * * * \\
(8.587)\end{array}$ & $\begin{array}{l}0.000 * * * \\
(7.804)\end{array}$ & $\begin{array}{l}0.000 * * * \\
(8.556)\end{array}$ & $\begin{array}{l}0.000 * * * \\
(6.706)\end{array}$ & $\begin{array}{l}0.000 * * * \\
(8.641)\end{array}$ & $\begin{array}{l}0.000 * * \\
(2.158)\end{array}$ \\
\hline sharemanu & $\begin{array}{l}-0.040 \\
(-0.931)\end{array}$ & $\begin{array}{l}-0.009 \\
(-0.226)\end{array}$ & $\begin{array}{l}-0.030 \\
(-0.818)\end{array}$ & $\begin{array}{l}0.016 \\
(0.330)\end{array}$ & $\begin{array}{l}-0.064 \\
(-1.456)\end{array}$ & $\begin{array}{l}-0.082 \\
(-1.577)\end{array}$ & $\begin{array}{l}-0.033 \\
(-0.912)\end{array}$ & $\begin{array}{l}-1.526 \\
(-0.254)\end{array}$ \\
\hline popu & $\begin{array}{l}-0.014 \\
(-1.184)\end{array}$ & $\begin{array}{l}-0.010 \\
(-0.823)\end{array}$ & $\begin{array}{l}-0.008 \\
(-0.559)\end{array}$ & $\begin{array}{l}-0.026^{*} \\
(-1.857)\end{array}$ & $\begin{array}{l}-0.010 \\
(-0.864)\end{array}$ & $\begin{array}{l}-0.030 * \\
(-1.949)\end{array}$ & $\begin{array}{l}0.007 \\
(0.465)\end{array}$ & $\begin{array}{l}0.375 \\
(0.240)\end{array}$ \\
\hline $\begin{array}{l}\text { Year fixed } \\
\text { effects }\end{array}$ & Yes & Yes & Yes & Yes & Yes & Yes & Yes & Yes \\
\hline $\begin{array}{l}\text { City fixed } \\
\text { effects }\end{array}$ & Yes & Yes & Yes & Yes & Yes & Yes & Yes & Yes \\
\hline Obs & 2177 & 2181 & 2172 & 2181 & 2176 & 2179 & 2170 & 2179 \\
\hline Sargan test & {$[0.202]$} & {$[0.116]$} & [0.400] & {$[0.108]$} & [0.484] & {$[0.288]$} & [0.213] & [0.958] \\
\hline $\begin{array}{l}\text { Durbin-Wu- } \\
\text { Hausman } \\
\text { test }\end{array}$ & {$[0.014]$} & {$[0.070]$} & [0.052] & {$[0.008]$} & [0.067] & {$[0.052]$} & [0.021] & [0.006] \\
\hline $\begin{array}{l}\text { First-stage } \\
F \text {-statistics }\end{array}$ & 14.99 & 21.97 & 270.34 & 9.63 & 15.62 & 14.23 & 285.97 & 10.03 \\
\hline
\end{tabular}

$t$ statistics in parentheses. * $p<0.1 ; * * p<0.05 ; * * * p<0.01$

Robustness test 1: Using the same matching criteria but measured in an earlier period in 2003

Robustness test 2: Using different matching criteria to find IV matches: GDP per capita $(G D P p c)$, average years of schooling (avedu), agglomeration (popu), and density (density) for the initial year of analysis (2007) 


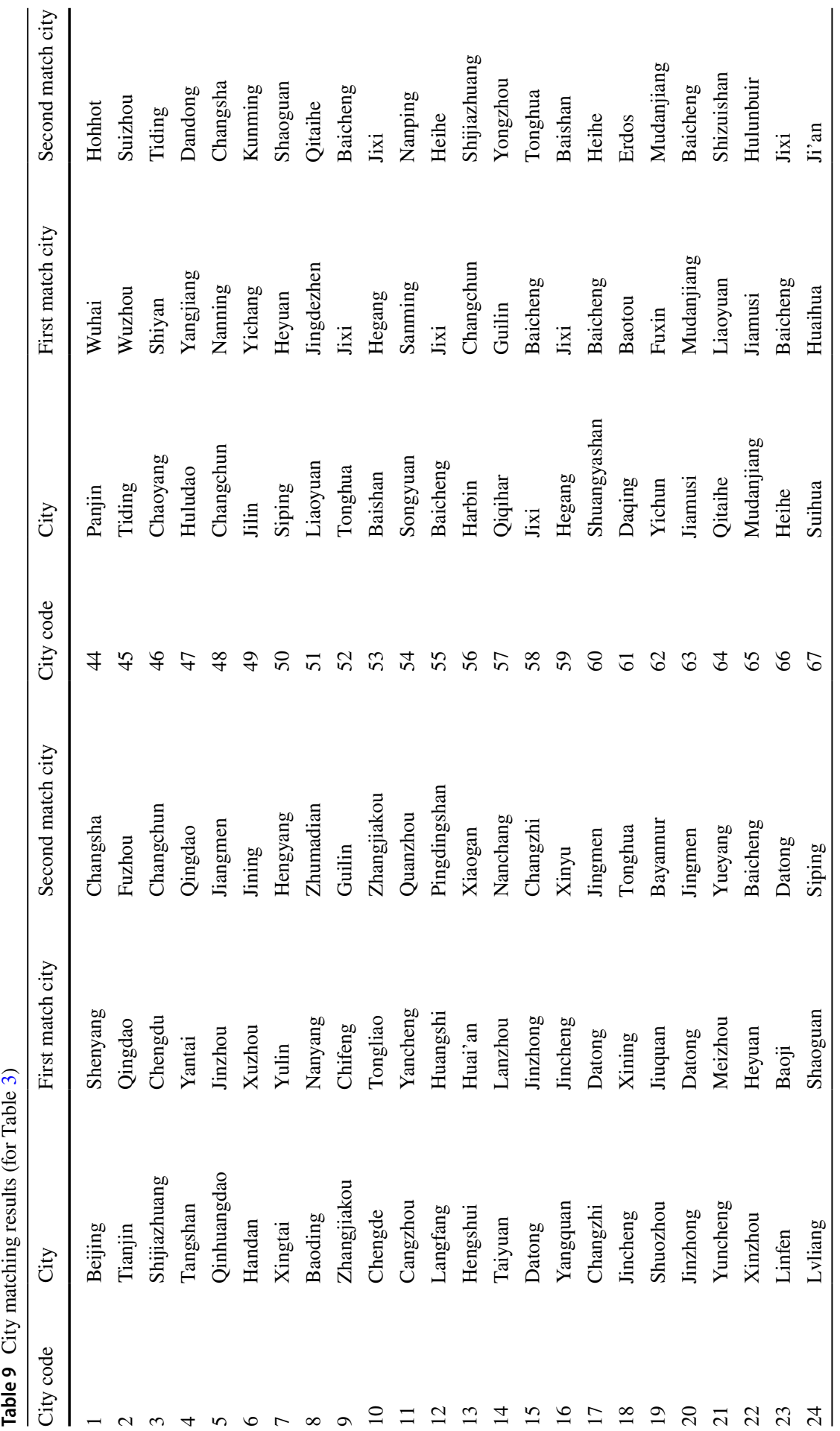




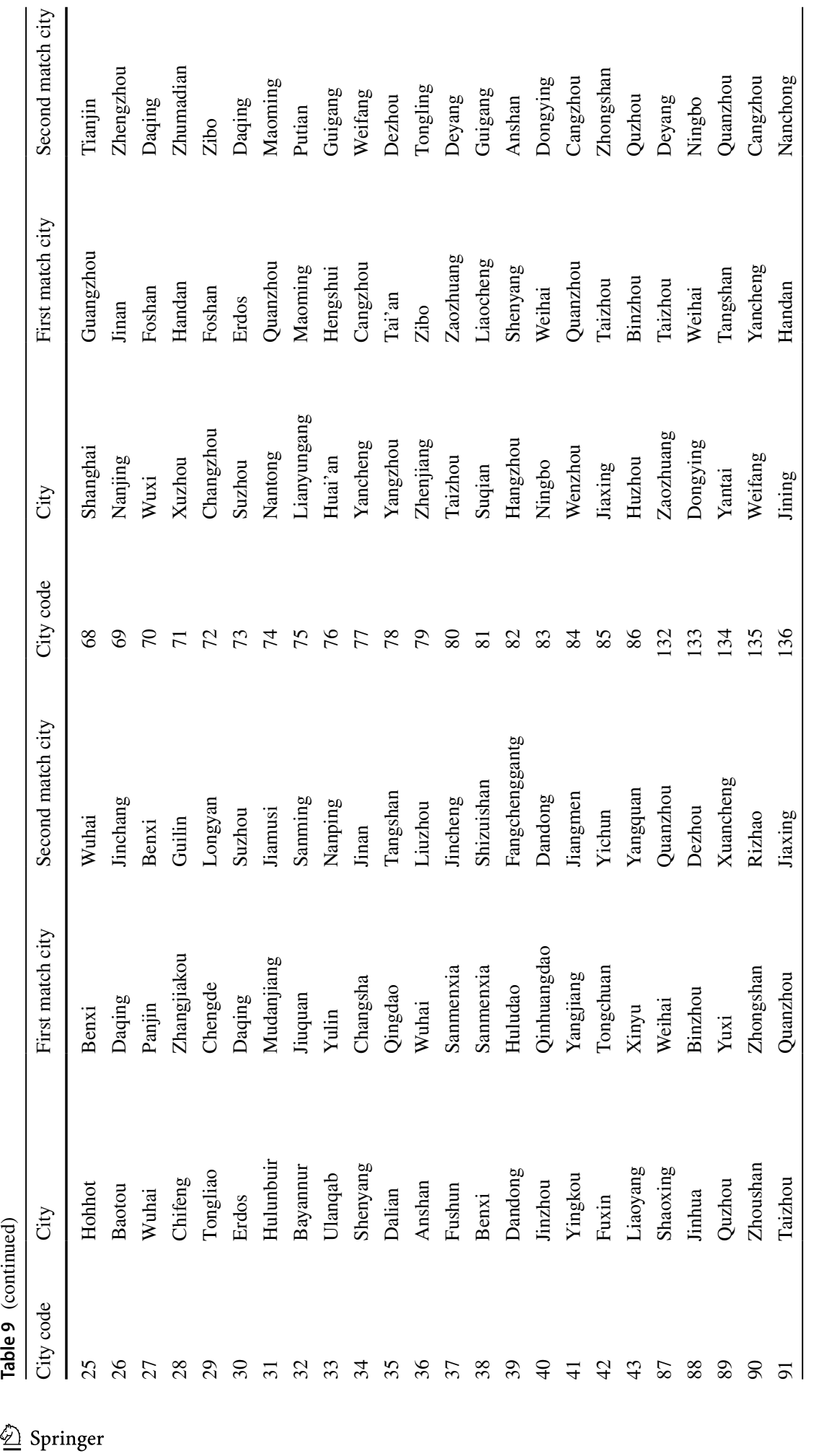




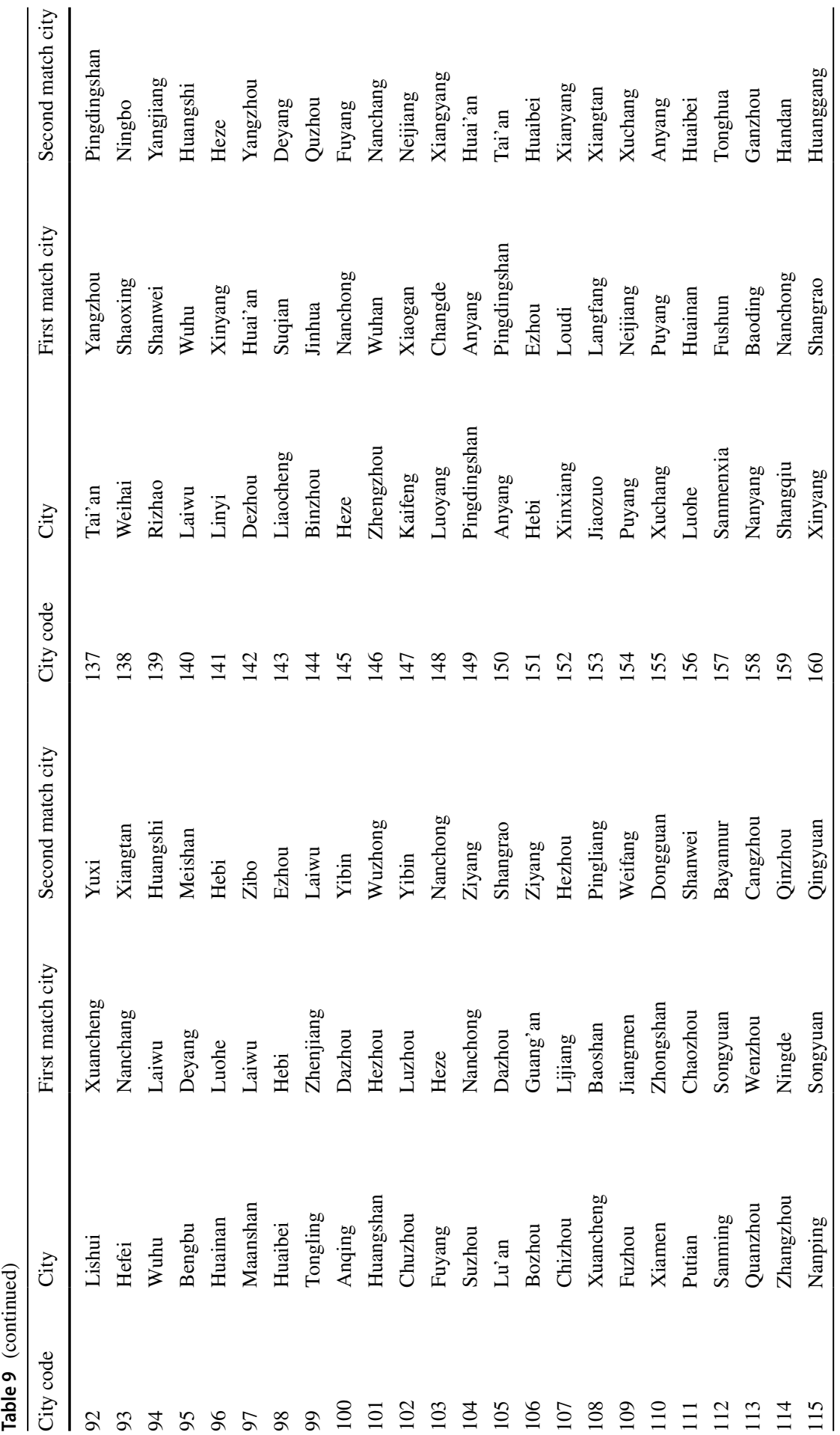




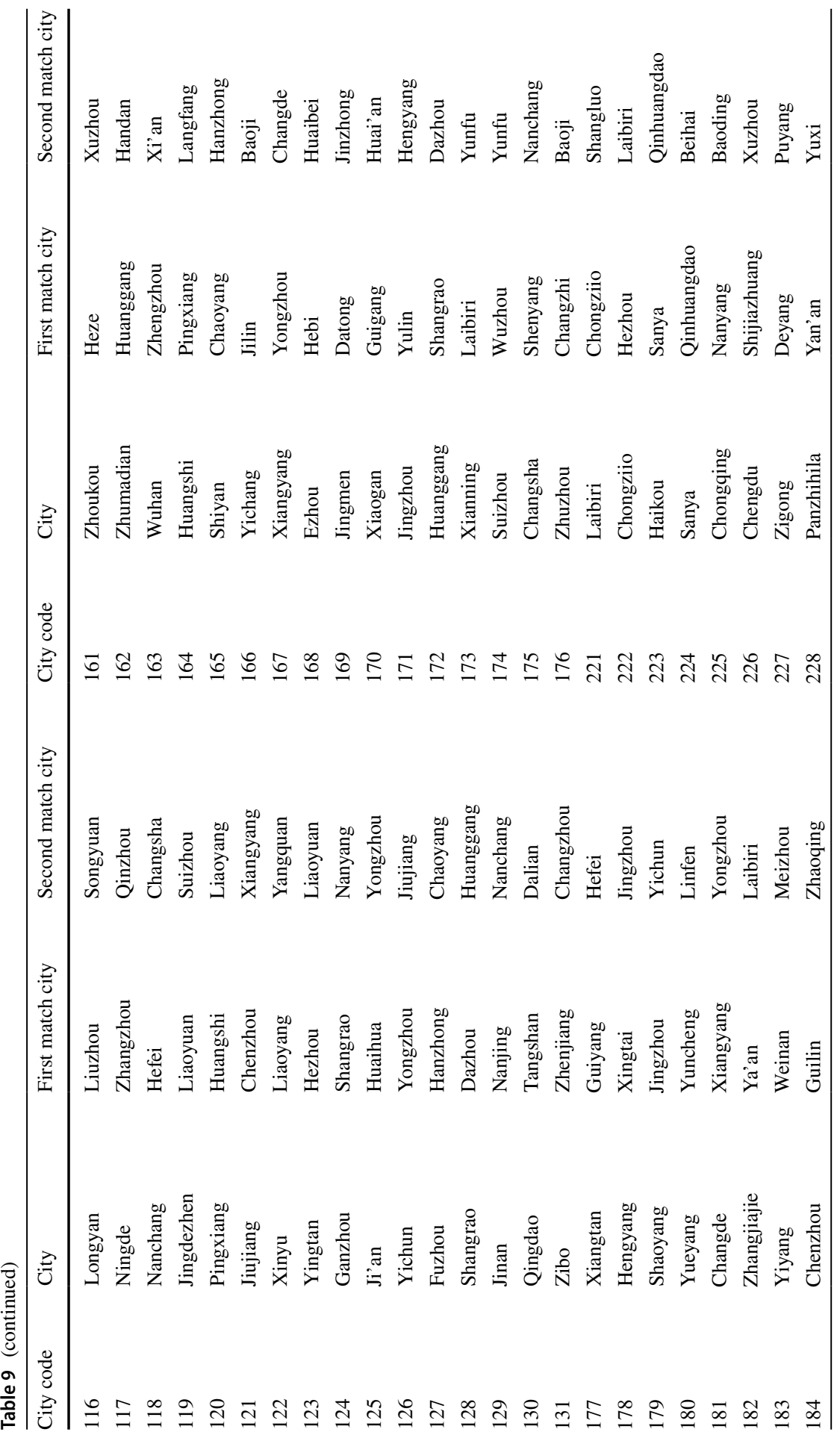




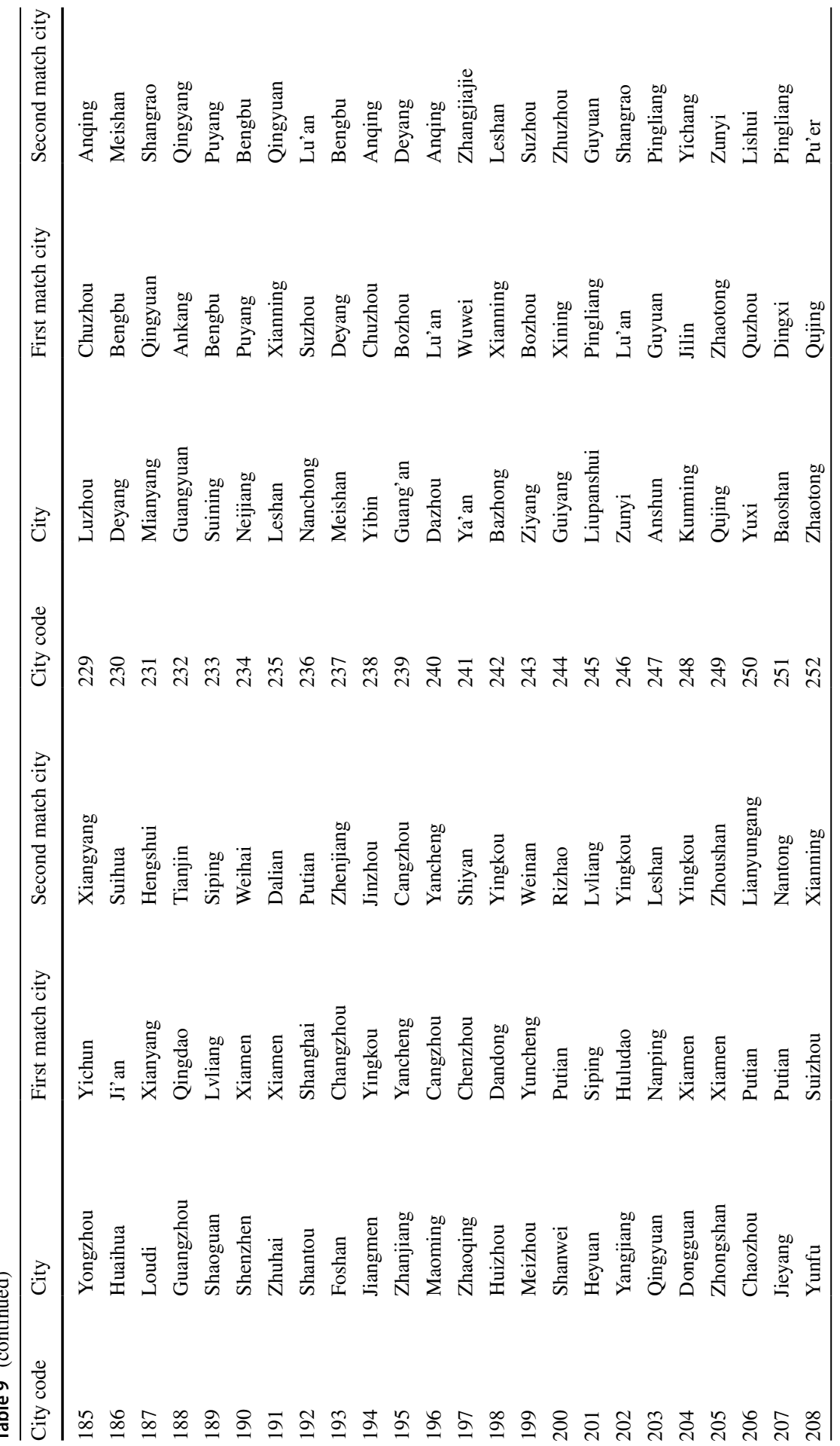




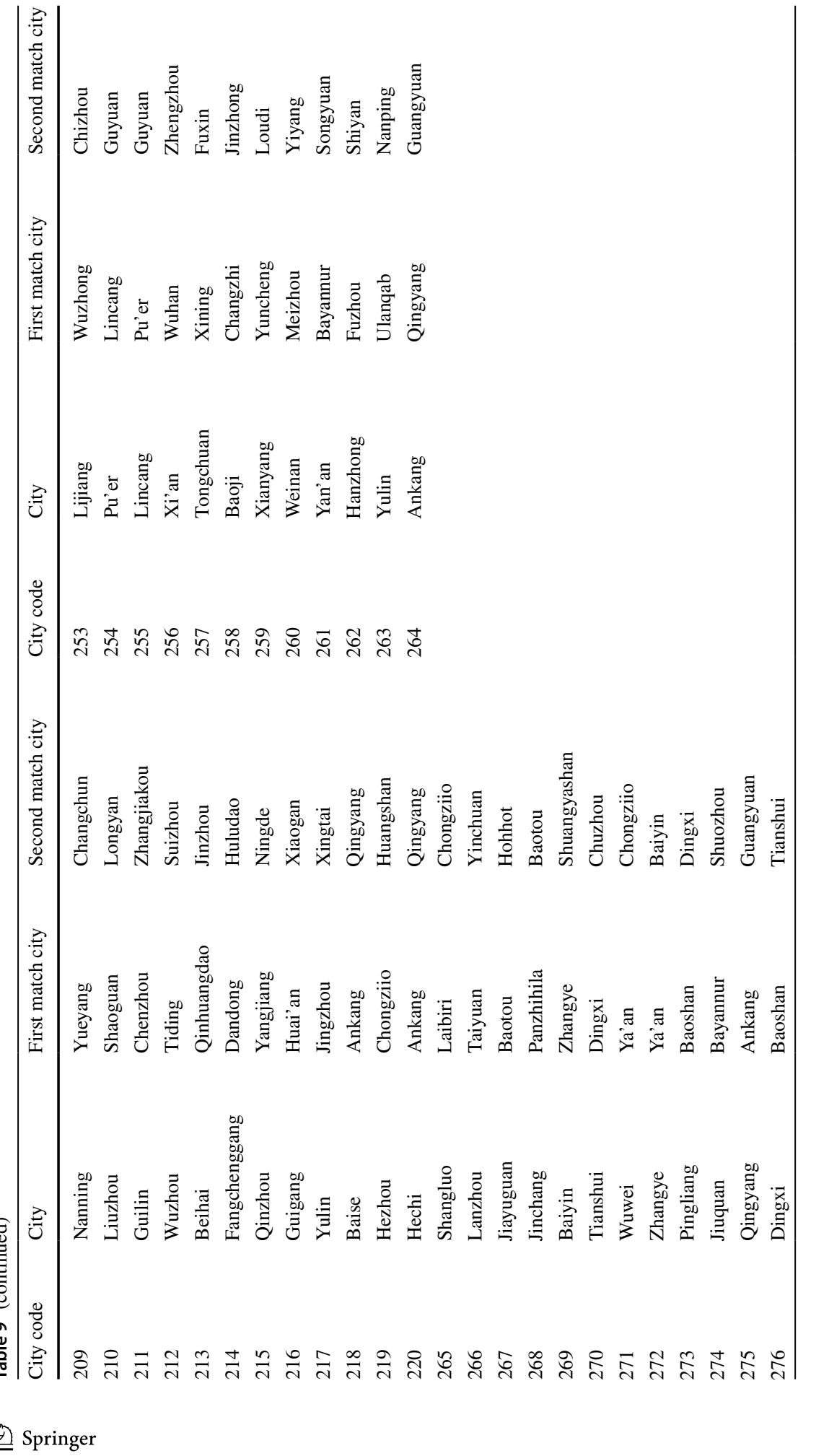




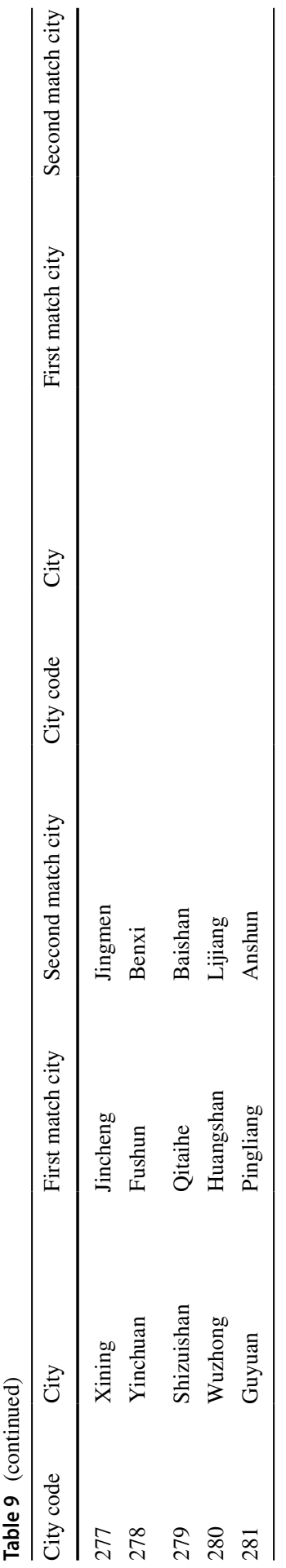




\section{References}

Acs ZJ, Anselin L, Varga A (2002) Patents and innovation counts as measures of regional production of new knowledge. Res Policy 31:1069-1085

Adamson DW, Clark DE, Partridge MD (2004) Do urban agglomeration effects and household amenities have a skill bias? J Reg Sci 44:201-224

Adhvaryu A, Kala N, Nyshadham A (2014) Management and shocks to worker productivity: evidence from air pollution exposure in an Indian garment factory. Working paper, University of Michigan

Agrawal A, Kapur D, McHale J (2008) How do spatial and social proximity influence knowledge flows? Evidence from patent data. J Urban Econ 64:258-269

Archsmith J, Heyes A, Saberian S (2018) Air quality and error quantity: pollution and performance in a high-skilled, quality-focused occupation. J Assoc Environ Resour Econ 5:827-863

Autor DH, Dorn D, Hanson GH (2013) The China syndrome: local labor market effects of import competition in the United States. Am Econ Rev 103(6):2121-2168

Bayer P, Keohane N, Timmins C (2009) Migration and hedonic valuation: the case of air quality. J Environ Econ Manag 58:1-14

Betz MR, Partridge MD (2013) Country road take me home: migration patterns in Appalachian America and place-based policy. Int Reg Sci Rev 36:267-295

Betz MR, Partridge MD, Fallah B (2016) Smart cities and attracting knowledge workers: which cities attract highly-educated workers in the 21st century? Pap Reg Sci 4:819-841

Boschma RA, Fritsch M (2009) Creative class and regional growth: empirical evidence from seven european countries. Econ Geogr 85(4):391-423

Bosker M, Brakman S, Garretsen H, Schramm M (2012) Relaxing Hukou: increased labor mobility and China's economic geography. J Urban Econ 72(2-3):252-266

Brueckner JK, Thisse J, Zenou Y (1999) Why is central Paris rich and downtown Detroit poor? An amenity-based theory. Eur Econ Rev 43:91-107

Carlino GA, Saiz A (2019) Beautiful city: leisure amenities and urban growth. J Reg Sci 59(3):369-408

Carlino GA, Chatterjee S, Hunt RM (2007) Urban density and the rate of invention. J Urban Econ 61:389-419

Chan KW (2009) The Chinese hukou system at 50. Eurasian Geogr Econ 50(2):197-221

Chang T, Graff Zivin J, Gross T, Neidell M (2016) Particulate pollution and the productivity of pear packers. Am Econ J Econ Policy 8:141-169

Chay KY, Greenstone M (2003) The impact of air pollution on infant mortality: evidence from geographic variation in pollution shocks induced by a recession. Q J Econ 118:1121-1167

Chen K, Kenney M (2007) Universities/research institutes and regional innovation systems: the cases of Beijing and Shenzhen. World Dev 35:1056-1074

Chen Y, Rosenthal SS (2008) Local amenities and life-cycle migration: do people move for jobs or fun? J Urban Econ 64:519-537

Chen Y, Ebenstein A, Greenstone M, Li H (2013) Evidence on the impact of sustained exposure to air pollution on life expectancy from China's Huai River policy. Proc Natl Acad Sci 110:12936-12941

Co C (2002) Evolution of the geography of innovation: evidence from patent data. Growth Change 33:393-423

Crescenzi R, Rodríguez Pose A (2013) R\&D, socio-economic conditions, and regional innovation in the US. Growth Change 44:287-320

Crescenzi R, Jaax A (2017) Innovation in Russia: the territorial dimension. Econ Geogr 93(1):66-88

Crescenzi R, Rodríguez-Pose A (2017) The geography of innovation in China and India. Int J Urban Reg Res 41(6):1010-1027

Crescenzi R, Rodríguez-Pose A, Storper M (2007) The territorial dynamics of innovation: a EuropeUnited States comparative analysis. J Econ Geogr 7:673-709

Crescenzi R, Rodríguez-Pose A, Storper M (2012) The territorial dynamics of innovation in China and India. J Econ Geogr 12:1055-1085

Crescenzi R, Nathan M, Rodríguez-Pose A (2016) Do inventors talk to strangers? On proximity and collaborative knowledge creation. Res Policy 45:177-194

Currie J, Neidell M (2005) Air pollution and infant health: what can we learn from California's recent experience? Quart J Econ 120:1003-1030 
Dalenberg DR, Partridge MD (1997) Public infrastructure and wages: public capital's role as a productive input and household amenity. Land Econ 73:268-284

Dalmazzo A, de Blasio G (2011) Amenities and skill-biased agglomeration effects: some results on Italian cities. Pap Reg Sci 90:503-527

Deller SC, Tsai TS, Marcouiller DW, English DB (2001) The role of amenities and quality of life in rural economic growth. Am J Agr Econ 83:352-365

Dorfman JH, Partridge MD, Galloway H (2011) Do natural amenities attract high-tech jobs? Evidence from a smoothed Bayesian spatial model. Spatial Econ Anal 6:397-422

Fagerberg J (1988) Why growth rates differ. In: Dosi G, Freeman C, Nelson R, Silverberg G, Soete L (eds). Pinter. (Reprinted), London, pp 432-457

Faggian A, McCann P (2009) Human capital, graduate migration and innovation in British regions. Camb J Econ 33:317-333

Fan P (2014) Innovation in China. J Econ Surv 28:725-745

Fan P, Wan G, Lu M (2012) China's regional inequality in innovation capability, 1995-2006. China World Econ 20:16-36

Feldman MP, Florida R (1994) The geographic sources of innovation: technological infrastructure and product innovation in the United States. Ann Assoc Am Geogr 84:210-229

Fitjar RD, Rodríguez-Pose A (2011) Innovating in the periphery: firms, values and innovation in southwest Norway. Eur Plan Stud 19:555-574

Fitjar RD, Rodríguez-Pose A (2015) Networking, context and firm-level innovation: cooperation through the regional filter in Norway. Geoforum 63:25-35

Florida R (2002a) The economic geography of talent. Ann Assoc Am Geogr 92:743-755

Florida R (2002b) The rise of the creative class. Wash Mon 34:15-25

Florida R (2014) The creative class and economic development. Econ Dev Q 28(3):196-205

Fujita M, Thisse J-F (2003) Does geographical agglomeration foster economic growth? and who gains and loses from it? Japan Econ Rev Japan Econ Assoc 54(2):121-145

Guo M, Fu S (2019) Running with a Mask? The effect of air pollution on marathon runners performance. J Sports Econ 20(7):903-928

Glaeser EL, Shapiro JM (2002) Cities and warfare: the impact of terrorism on urban form. J Urban Econ 51:205-224

Glaeser EL, Kolko J, Saiz A (2001) Consumer city. J Econ Geogr 1:27-50

Gordon IR, McCann P (2005) Innovation, agglomeration, and regional development. J Econ Geogr 5:523-543

Graves PE (1980) Migration and climate. J Reg Sci 20:227-237

Graves PE, Mueser PR (1993) The role of equilibrium and disequilibrium in modeling regional growth and decline: a critical reassessment. J Reg Sci 33:69-84

Griliches Z (1979) Issues in assessing the contribution of R\&D to productivity. Bell J Econ 10:92-116

Griliches Z (1986) Productivity, R\&D and basic research at firm level in the 1970s. Am Econ Rev 76:141-154

Griliches Z (1990) Patent statistics as economic indicators: a survey. J Econ Lit 28:1661-1707

Gyourko J, Tracy J (1991) The structure of local public finance and the quality of life. J Polit Econ 99:774-806

Hagedoorn J, Cloodt M (2003) Measuring innovative performance: is there an advantage in using multiple indicators? Res Policy 32:1365-1379

He J, Huang X, Xi G (2018a) Urban amenities for creativity: an analysis of location drivers for photography studios in Nanjing, China. Cities 74:310-319

He J, Liu H, Salvo A (2018b) Severe air pollution and labor productivity: evidence from industrial towns in China. Am Econ J Appl Econ Assoc 11(1):173-201

Jaffe AB (1986) Technological opportunity and spillovers of R\&D: evidence from firms' patents, profits and market value. Am Econ Rev 76:984-1001

Kafouros M, Wang C, Piperopoulos P, Zhang M (2015) Academic collaborations and firm innovation performance in China: the role of region-specific institutions. Res Policy 44:803-817

Kahn ME, Zheng S (2016) Blue skies over Beijing: economic growth and the environment in China. Princeton University Press, Princeton

Kuckiki A, Tsuji M (2010) From Agglomeration to Innovation: upgrading industrial clusters in emerging economies_edited by Akifumi Kuckiki and Masatsugu Tsuji. Asian-Pac Econ Lit 24:178-179

Lavy V, Ebenstein A, Roth S (2014) The impact of short term exposure to ambient air pollution on cognitive performance and human capital formation. National Bureau of Economic Research 
Lee N, Rodríguez-Pose A (2014) Creativity, cities, and innovation. Environ Plan A 46:1139-1159

Lehmann EE, Seitz N (2017) Freedom and innovation: a country and state level analysis. J Tech Transfer 42(5):1009-1029

Li X (2009) China's regional innovation capacity in transition: an empirical approach. Res Policy 38:338-357

Li M, Goetz SJ, Partridge M, Fleming DA (2016) Location determinants of high-growth firms. Entrep Reg Dev 28:97-125

Lichter A, Pestel N, Sommer E (2017) Productivity effects of air pollution: evidence from professional soccer. Labor Econ 48:54-66

Liu Y, Shen J (2014) Jobs or amenities? Location choices of interprovincial skilled migrants in China, 2000-2005. Popul Space Place 20(7):592-605

Lund L (1986) Locating corporate R\&D facilities. Conference Board, New York

Malgouyres C (2017) The impact of Chinese import competition on the local structure of employment and wages: evidence from France. J Reg Sci 57(3):411-441

Mansfield E (1986) Patents and innovation: an empirical study. Manag Sci 32:173-181

Maslow AH (1943) A theory of human motivation. Psychol Rev 50(4):370-396

Maslow AH (1954) Motivation and personality. Harper and Row, New York

Mate-Sanchez-Val M, Harris R (2014) Differential empirical innovation factors for Spain and the UK. Res Policy 43:451-463

Morgan K (2004) The exaggerated death of geography: learning, proximity and territorial innovation systems. J Econ Geogr 4(1):3-21

Mulligan GF, Carruthers JI (2011) Amenities, quality of life, and regional development. In: Investigating quality of urban life. Springer, pp 107-133

Neidell MJ (2004) Air pollution, health, and socio-economic status: the effect of outdoor air quality on childhood asthma. J Health Econ 23(6):1209-1236

Partridge MD (2010) The dueling models: nEG vs amenity migration in explaining US engines of growth. Pap Reg Sci 89:513-536

Partridge MD, Rickman DS, Ali K, Olfert MR (2008) The geographic diversity of US nonmetropolitan growth dynamics: a geographically weighted regression approach. Land Econ 84:241-266

Partridge MD, Rickman DS, Olfert MR, Tan Y (2017) International trade and local labor markets: do foreign and domestic shocks affect regions differently? J Econ Geogr 17(2):375-409

Pun VC, Manjourides J, Suh H (2017) Association of ambient air pollution with depressive and anxiety symptoms in older adults: results from the NSHAP study. Environ Health Perspect 125:342-348

Rappaport J (2007) Moving to nice weather. Reg Sci Urban Econ 37:375-398

Roback J (1982) Wages, rents, and the quality of life. J Polit Econ 90:1257-1278

Roback J (1988) Wages, rents, and amenities: differences among workers and regions. Econ Inq 26(1):23-41

Rodriguez-Pose A, Crescenzi R (2006) R\&D, spillovers, innovation systems and the genesis of regional growth in Europe. ERSA conference papers ersa06. European Regional Science Ass, 371p

Rodríguez-Pose A, Crescenzi R (2008) Research and development, spillovers, innovation systems, and the genesis of regional growth in Europe. Reg Stud 42:51-67

Rodríguez-Pose A, Villarreal Peralta EM (2015) Innovation and regional growth in Mexico: 2000-2010. Growth Change 46:172-195

Rodríguez-Pose A, Wilkie C (2016) Putting China in perspective: a comparative exploration of the ascent of the Chinese knowledge economy. Cambr J Reg Econ Soc 9:479-497

Rodríguez-Pose A, Zhang M (2019) Government institutions and the dynamics of urban growth in China. J Reg Sci 59(4):633-668

Rong Z, Wu X, Boeing P (2017) The effect of institutional ownership on firm innovation: evidence from Chinese listed firms. Res Policy 46:1533-1551

Rosen S (1974) Hedonic prices and implicit markets: product differentiation in pure competition. J Polit Econ 82:34-55

Rundell KW (2012) Effect of air pollution on athlete health and performance. Br J Sports Med 46:407-412

Sleuwaegen L, Boiardi P (2014) Creativity and regional innovation: evidence from EU regions. Res Policy 43:1508-1522

Smit MJ, Abreu MA, Groot HL (2015) Micro-evidence on the determinants of innovation in the Netherlands: the relative importance of absorptive capacity and agglomeration externalities. Pap Reg Sci 94:249-272 
Song H, Zhang M (2017) Spatial spillovers of regional innovation: evidence from Chinese provinces. Emerg Markets Finance Trade 53:2104-2122

Stafford HA, Galzerano EA, Kelley JA (1984) The effects of environmental regulations on industrial location. Department of Geography, University of Cincinnati, Cincinnati

Stephens HM, Partridge MD (2015) Lake Amenities, environmental degradation, and Great Lakes regional growth. Int Reg Sci Rev 38:61-91

Stephens HM, Partridge MD, Faggian A (2013) Innovation, entrepreneurship and economic growth in lagging regions. J Reg Sci 53:778-812

Su Y, Hua Y, Liang X (2019) Toward job or amenity? Evaluating the locational choice of internal migrants in China. Int Reg Sci Rev 42(5-6):400-430

Sun Y (2000) Spatial distribution of patents in China. Reg Stud 34:441-454

Sun Y (2003) Geographic patterns of industrial innovation in China during the 1990s. Tijdschrift Voor Economische En Sociale Geografie 94:376-389

Sun C, Zheng S, Wang J, Kahn ME (2019) Does clean air increase the demand for the consumer city? Evidence from Beijing. J Reg Sci 59(3):409-434

Tiebout CM (1956) A pure theory of local expenditures. J Polit Econ 64:416-424

Ullman EL (1954) Amenities as a factor in regional growth. Geogr Rev 44:119-132

Wu W, Dong G (2014) Valuing the "green" amenities in a spatial context. J Reg Sci 54(4):569-585

Wu J, Zhuo S, Wu Z (2017) National innovation system, social entrepreneurship, and rural economic growth in China. Technol Forecast Soc Chang 121:238-250

World Bank. https://data.worldbank.org/indicator/NY.GDP.PCAP.CD?locations=CN

Zandiatashbar A, Hamidi S (2018) Impacts of transit and walking amenities on robust local knowledge economy. Cities 81:161-171

Zheng L (2016) What city amenities matter in attracting smart people? Pap Reg Sci 95:309-327

Zheng S, Kahn ME (2013a) Does government investment in local public goods spur gentrification? Evidence from Beijing. Real Estate Econ 41:1-28

Zheng S, Kahn ME (2013b) Understanding China's urban pollution dynamics. J Econ Lit 51:731-772

Zheng S, Fu Y, Liu H (2009) Demand for urban quality of living in China: evolution in compensating land-rent and wage-rate differentials. J Real Estate Finance Econ 38:194-213

Zheng S, Kahn ME, Liu H (2010) Towards a system of open cities in China: home prices, FDI flows and air quality in 35 major cities. Reg Sci Urban Econ 40:1-10

Zivin JG, Neidell M (2012) The impact of pollution on worker productivity. Am Econ Rev 102:3652-3673

Publisher's Note Springer Nature remains neutral with regard to jurisdictional claims in published maps and institutional affiliations. 